https://helda.helsinki.fi

\title{
The Palaeontology of Browsing and Grazing
}

\section{Saarinen, Juha}

Springer

2019-11

Saarinen , J 2019 , The Palaeontology of Browsing and Grazing . in The Ecology of

Browsing and Grazing II . 1 edn , Ecological Studies , no. 1 , vol. 239 , Springer , pp. 5-59 . https://doi.org/10.1007/9

http://hdl.handle.net/10138/336308

https://doi.org/10.1007/978-3-030-25865-8_2

unspecified

acceptedVersion

Downloaded from Helda, University of Helsinki institutional repository.

This is an electronic reprint of the original article.

This reprint may differ from the original in pagination and typographic detail.

Please cite the original version. 


\title{
Chapter 2 \\ The Palaeontology of Browsing and Grazing
}

\author{
Juha Saarinen
}

\subsection{Introduction}

Throughout their evolutionary history herbivorous mammals have encountered drastic climatic and environmental changes, which have led to changes in their diet and adaptations to feeding on various plant materials. The most abundant large herbivorous mammals are the ungulates, large hooved laurasiatherian mammals, which have an extensive fossil record on most continents (except Australia and Antarctica) throughout the Cenozoic era (ca. 65 million years to present). They were the dominant large herbivores in terrestrial ecosystems during the Cenozoic, although some groups, such as pigs (Suidae), include omnivorous forms as well. Many lineages of large herbivorous land mammals have experienced drastic changes in their feeding ecology during the Cenozoic following global and local changes in climate and vegetation (Janis 1993, 2008; Strömberg 2011). The most prominent of these dietary changes is the gradual shift from browsing to various degrees of grazing in many ungulate groups, especially during the latter part of the Cenozoic known as the Neogene (ca. 23 million years to present), following global climatic cooling and the spread of grasslands (Janis 2008). Eventually this led to the evolution of a few lineages of specialised grazing ungulates (mostly among equids and some bovids) during the last few million years (Janis 2008). This was achieved by changes in the digestive system (e.g., Ilius and Gordon 1992; Gordon 2003; Clauss and Rössner 2014) and by increasing wear-resistance of the molar teeth, which are used for grinding food (e.g., Janis and Fortelius 1988). Complex enamel patterns and increased crown heights (hypsodonty) evolved in many large bodied grass-eating mammal lineages (Janis and Fortelius 1988; Fortelius et al. 2002; Janis

\footnotetext{
J. Saarinen ( $\triangle)$

Natural History Museum, London, UK

University of Helsinki, Helsinki, Finland

e-mail: juha.saarinen@helsinki.fi
} 
et al. 2002, 2004; Fortelius et al. 2006; Janis 2008; Damuth and Janis 2011). A similar overall pattern occurred in the other major large herbivorous mammal groups, such as proboscideans (relatives of the modern elephants), xenarthrans (sloths and armadillo-like, herbivorous glyptodonts) and large herbivorous marsupials (e.g., Lister 2013; Vizcaíno 2009; Janis et al. 2016).

Browsing refers to feeding on various woody and non-woody dicotyledonous plants, including leaves, shoots and bark of trees, shrubs and dicotyledonous herbs, whereas grazing means eating grass. The most common feeding strategy in extant (and many fossil) ungulates is, however, feeding on various proportions of both browse and grass. This is called mixed-feeding. According to the traditional classification, browsers are defined as having less than $10 \%$ grass in their diet, mixedfeeders as having between $10 \%$ and $90 \%$ grass in diet, and grazers as having more than 90\% grass in diet (e.g., Hofmann and Stewart 1972; Fortelius and Solounias 2000). These dietary classes enable simple categorisation of ungulate diets, but there is a continuum of herbivorous species from those utilising almost no grass to those feeding almost exclusively on grass, and this can also vary to some extent between populations of a species according to available vegetation and presence of competing ungulate species (e.g., Rivals et al. 2015; Rivals and Lister 2016; Saarinen et al. 2016; Saarinen and Lister 2016). In this chapter I use the term "frugivore" for mammals feeding mostly on fruits and seeds, whereas the term "folivore" is occasionally used as a synonym of "browser" to specify diets based on leaves and shoots particularly, rather than feeding on fruits (frugivorous diet) or both fruits and leaves (frugivorous-folivorous diet) (see Blondel 2001).

Broadly the trend in the evolution of ungulate faunas since the Mid-Miocene (ca. $16 \mathrm{Ma}$ ) has been towards increasing numbers of grazing-adapted species and subsequently a decline in the number of specialized browsing species, but the details are, of course, much more complex depending on local habitats and resources (Janis et al. 2002; Janis 2008). In the past, researchers often used generalized interpretations about diet based on the ecomorphology (e.g., hypsodonty) of herbivorous mammal species. However, diets can vary considerably within species, and many simplified ecomorphological characteristics (such as hypsodonty of teeth) can reflect adaptations to other environmental factors than dietary composition (see further discussion in the next section). This has been clearly demonstrated for many extant and extinct mammals by dietary analyses based on proxy methods such as dental micro- and mesowear and stable isotope analyses (see next section). Dietary adaptations in extant (and Pleistocene Eurasian) ungulate families are variable. Deer (Cervidae) have in general retained relatively unspecialized, browse-based diets required for sufficient nutrient intake for the seasonal growing of antlers (Geist 1998). This is reflected in their relatively unspecialized, mostly low-crowned (brachydont) and simple dentitions (Geist 1998). Also rhinoceroses (Rhinocerotidae) have mostly retained browsedominated diets and brachydont dentitions, but unlike the deer, some rhinoceros species such as the Pleistocene woolly rhinoceros (Coelodonta antiquitatis), the extant African white rhinoceros (Ceratotherium simum) and especially the late Neogene elasmotheriines evolved into grazers with relatively hypsodont dentitions (e.g., Janis 2008). Bovids (Bovidae) and derived horses (Equidae, Equinae) thrived in 
the Pleistocene and recent environments by mostly evolving towards increasingly specialized grazing diets (e.g., by increasing hypsodonty and dental complexity) (e.g., Janis 2008).

\subsection{Browsing and Grazing in Fossil Ungulates: What Tooth Wear, Stable Isotopes and Morphological Adaptations Tell us About Diets in the Past}

\subsubsection{Ecomorphology: Evolutionary Adaptations to Browsing and Grazing}

\subsubsection{Overall Morphology}

Many skeletal adaptations of mammals, especially in the skull, reflect their feeding ecology. For example, the skulls of the plesiomorphic browsing ungulates tend to have narrow muzzles, moderate-sized attachment surfaces for the masseter muscles, comparatively large attachment surfaces for the temporalis muscles and relatively shallow jaws holding low-crowned teeth, whereas the more derived grazers usually have wider muzzles, deeper jaws facilitating more high-crowned teeth, posteriorlylocated orbits and larger attachment surfaces for the masseter muscles (Janis 1995). Many specialised browsers, such as moose, tapir and many fossil ungulates, have retracted nasals, indicating the presence of a large, flexible upper lip or a proboscis for effective collecting of leaves and other plant parts. Grazing rhinoceroses tend to have backwards-inclined occipital surfaces in their skulls, reflecting a downwardsoriented head posture, whereas in browsing rhinos the occiput is vertical, reflecting a more horizontal head posture (Loose 1975). However, the most prominent clues to dietary adaptations are found in the dentition, as shown in the following two sections.

\subsubsection{Hypsodonty}

Hypsodonty refers to (relative) tooth crown height. It is typically measured as a ratio between tooth crown height and the length or width of the occlusal surface of a tooth, but often it is enough to assign the teeth to three commonly used categories of hypsodonty, which are: (1) brachydont (low-crowned), (2) mesodont (mediumcrowned) and (3) hypsodont (high-crowned) (Janis and Fortelius 1988; Fortelius et al. 2002). All herbivorous mammal lineages started as brachydont but many show increase in tooth crown height later during their evolutionary history. An increase in tooth crown height is perhaps the most universal response in herbivorous mammals to increase the durability of their molar teeth in response to increased tooth wear rates caused by abrasive dietary items (Janis and Fortelius 1988). Traditionally it was 
thought that hypsodonty is specifically an adaptation to grazing, as chewing on tough, fibrous grasses with phytoliths (small mineral particles within grass leaves) abrades the teeth causing increased wear rates (Damuth and Janis 2014). However, another possibility is the general increase of hypsodonty in dry, open environments where exogenous grit on the plant food (following dust accumulation or soil ingestion) could abrade the teeth heavily (e.g., Damuth and Janis 2011; Madden 2015). Several studies indicate that both grazing, exogenous grit especially in dry, open environments, and sometimes even the accumulation of volcanic ash, can accelerate tooth wear and are likely to have contributed to the evolution of hypsodont dentitions in herbivorous mammals (e.g., Fortelius et al. 2002; Damuth and Janis 2011, 2014; Strömberg et al. 2013; Madden 2015). Whatever the ultimate cause, hypsodonty in extant ungulates is nonetheless most common and prominent in grazing forms such as modern horses.

However, the correlation between hypsodonty and grazing only reflects evolutionary adaptation and it does not give more detailed information about dietary variation within species, sometimes even between species. There are several exceptions to the hypsodonty-grazing connection: the extant hippopotamus (Hippopotamus amphibius) has brachydont molars despite being a grass-dominated feeder and some hypsodont mammals, such as the extant pronghorn (Antilocapra americana) and the takin (Budorcas taxicolor) have browse-dominated mixed-feeding diets in their extant populations. Many small mammals developed ever-growing, rootless (hypselodont) dentition to cope with very high tooth wear rates, but in large herbivorous mammals this only happened in a few specialised species, the most intriguing examples being the Plio-Pleistocene rhinoceroses of the genus Elasmotherium and many endemic South American notoungulates (OrtizJaureguizar and Cladera 2006). Why hypselodonty evolved only in a few specialised lineages of ungulates is due to the problem of maintaining a complex occlusal morphology once enamel has worn away, unless new enamel is constantly erupting (Janis and Fortelius 1988). A notable exception to the scarcity of hypseolodonty in large herbivorous mammals is the Xenarthra (the major clade of placental mammals including sloths, anteaters and armadillos), all of which have hypselodont dentitions, because, as their teeth lack enamel, their tooth wear rate is high regardless of the abrasiveness of their diet (Vizcaíno 2009).

\subsubsection{Tooth Morphology and Complexity of Enamel Patterns in Large Herbivorous Mammals}

Another way to increase the efficiency of molar teeth is to increase the complexity of enamel patterns on the occlusal surface (Janis and Fortelius 1988). This creates an increasingly complex system of enamel ridges for shearing through tough plants, such as fibrous browse and especially grass.

Mammal teeth are complex in structure and require precise occlusion to function effectively (Ungar 2010). However, this complex system of tooth structure and chewing enables herbivorous mammals to process many kinds of plant foods 
effectively. The early evolution of mammal dentition during the Mesozoic saw the development of offset upper and lower molar positions (enabling precise occlusion between the upper and lower dentitions), and a triangular construction where three principal cusps in upper molars (protocone, paracone and metacone) form a triangle (trigon) matching a similar (but reverse) construction in the lower molars (trigonid) (Ungar 2010). In more derived tribosphenic molars, a talonid basin was formed in the lower molars by the addition of hypoconid, entoconid and hypoconulid cusps behind the trigonid. Finally, in quadritubercular or eutheromorphic molars, the evolution of another cusp (hypocone) formed the plesiomorphic upper molar morphology of most omnivorous/herbivorous mammals consisting of four principal cusps, while in the lower molars the trigonid and talonid basins became equally sized an often partially fused, also becoming surrounded mainly by four principal cusps (Ungar 2010). This was the starting point of the evolution of herbivorous mammal dentitions during the Cenozoic.

The earliest ungulates, and many other groups of herbivorous mammals such as proboscideans, started their dental evolution from brachydont (low-crowned) molars with the four principal cusps as separate knobs on the tooth surface (bunodont dental morphology) (e.g., Rose 2006; Ungar 2010). These kinds of bunodont dentitions are typical for omnivorous and frugivorous (fruit eating) mammals, and are still seen today (although usually with more complex pattern of cusps) in omnivorous herbivores such as the wild boar (Sus scrofa) and many other suids (e.g., Janis 2008; Ungar 2010). Bunodont molars function best in rather unspecialised crushing of various food items (including fruit, seeds and other plant material), whereas the more derived lophodont, selenodont and plagiolophodont molar morphologies of browsing and grazing herbivorous mammals are more optimal for cutting and shearing tough plant material such as branches, leaves and grass (Ungar 2010). When herbivorous mammals started to adapt to consuming tough plant material (dicotyledonous leaves rather than fruit and other softer plant parts), increasingly effective cutting ridges started to evolve between the cusps on the tooth surfaces. This commonly led to the evolution of bilophodont molars where the anterior pair and the posterior pair of principal cusps are connected by two transverse cutting blades, or lophodont (trilophodont or ectolophodont) molars where, in addition to the transverse lophs, there is a prominent outer loph (ectoloph) running longitudinally on the buccal (cheek) side of the tooth (e.g., Fortelius 1985). With the consumption of increasingly tough dietary items, especially grass, these features became more complicated with complex folding and fusion of the lophs, and sometimes added lophs or other ridges (Janis and Fortelius 1988; Janis 2008). These molars with complex folding and fusion of lophs are called plagiolophodont, and they are often further strengthened by extensive dental cement filling gaps between the lophs (Fortelius 1985).

Many artiodactyls, most importantly ruminants and camels, evolved another kind of advanced tooth morphology known as selenodonty (analogous to lophodonty), where the four principal cusps of the molars are elongated into crescent-shaped, longitudinal crests (analogous to lophs), enabling effective processing of plant material (Fortelius 1985). Also selenodont molars often became structurally more 
complex (becoming convergent to plagiolophodonty) in grazers, such as many grazing bovids (Fortelius 1985). One recently discovered dental adaptation specifically for processing grass-dominated diets in woodland and wetland habitats is the structural fortification of cusps (Žliobaitè et al. 2016, 2018). Molars with structurally fortified cusps are particularly typical in many selenodont ruminants that live in woodland and wetland habitats and feed on fresh grasses, such as water buffalos, reduncine antelopes and axis deer, but similar adaptations are also seen in suids, hippos and other herbivorous mammals (Žliobaite et al. 2018).

These are the common ways that most large herbivorous mammals, such as ungulates and marsupials, increased the complexity of the occlusal surface of their molar teeth. However, slightly different processes occurred in proboscideans (elephants and their fossil relatives) and herbivorous xenarthrans (sloths and armadillos). The proboscideans started as bunodont, but quite early in their evolution their molars evolved extra pairs of cusps, which were arranged so that they form multiple transverse rows or "lophids" together with smaller accessory cusps, except for deinotheres (Deinotheriidae), which had bilophodont molars similar to some browsing ungulates such as tapirs (Sanders et al. 2010). In mammutid proboscideans the cusp pairs were compressed and formed cutting lophs. Finally, in true elephants, the cusp rows or lophids fused into narrow ridges called lamellae or "plates", which multiplied in number and were bound together with extensive dental cement (loxodont or lamellar tooth morphology). In elephants, an increase in hypsodonty and lamellar count through time also occurred within genera, such as in the mammoth lineage (Mammuthus) (Lister et al. 2005). The xenarthrans had peculiar dentitions without the hard, wear-resistant enamel, so their molariform teeth are often simplified in shape (Vizcaíno 2009). Nonetheless, differences between the hardness of differentiated dentine in xenarthran teeth created ridges analogous to the enamel ridges in other placental teeth as the teeth were worn, such as the bilophodont worn shape typical of browsing sloths and the multi-lobed morphology of the glyptodonts (giant herbivorous relatives of armadillos).

\subsubsection{Dietary Proxy Methods}

\subsubsection{Microwear}

Microwear analysis is the first proxy method for reconstructing diets of fossil mammals based on tooth wear (Walker et al. 1978), by counting the abundance of different kinds of microscopic scratches and pits on tooth enamel caused by chewing different kinds of food objects (Fig. 2.1). The hypothesis behind that method is that during the tooth wear abrasive plant material (such as grass phytoliths) cause long scratches on the worn enamel facets of the teeth, whereas browse does not: in the latter case the microscopic wear pattern is more pitted. The benefit of this method is that it is applicable to virtually all kinds of teeth and it should give consistent results for mammals with very different tooth morphologies. However, microwear analysis 
1 .

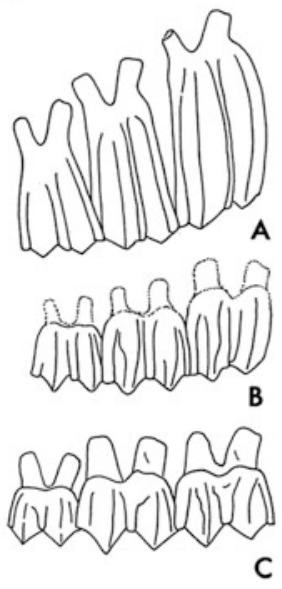

2. A

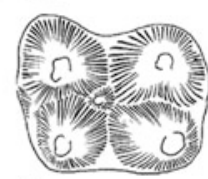

$\mathrm{D}$

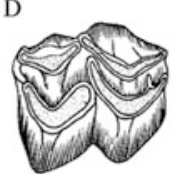

G

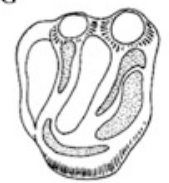

B

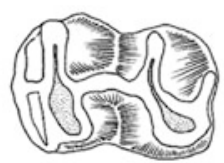

E
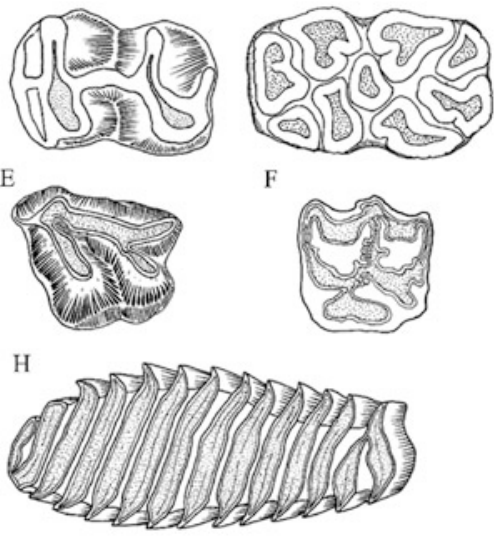

Fig. 2.1 Examples of hypsodonty and molar morphology in herbivorous mammals. (1) Hypsodonty categories: $\mathrm{A}=$ hypsodont, $\mathrm{B}=$ mesodont, $\mathrm{C}=$ brachydont. Image from: Fortelius et al. (2002). (2) Examples of tooth morphogy types of herbivorous mammals. A. Bunodont (peccary). B. Bilophodont (kangaroo). C. Columnar (warthog). D. Selenodont (deer). E. (Ecto-) Lophodont (rhinoceros). F. Plagiolophodont (horse). G. Bunolophodont (rodent-woodchuck). H. Lamellar (rodent—capybara). Image from: Janis and Fortelius (1988). (Permits to re-use the figures have been received from the original authors and publishers)

only reveals the last few meals of the animal instead of long-term average dietary signal (e.g., Rivals et al. 2010). Furthermore, it has been suggested that other factors than diet, such as external soil material from the environment, may obscure the dietary signal provided by microwear analysis (Rivals et al. 2010). On the other hand, microwear can, for example, reveal feeding on hard seeds, which the other proxy methods do not pick up (Rivals et al. 2012). Ungar et al. (2003) developed a new practical method for analysing microwear surface textures by combining confocal microscopy with scale-sensitive fractal analysis (the dental microwear texture analysis, Scott et al. 2005). This methodological improvement has made dietary analyses based on microscopic tooth wear patterns more objective compared to the original method based on visual counting of scratches and pits.

\subsubsection{Mesowear}

Mesowear analysis (Fortelius and Solounias 2000) is based on the empirical observation that increasing abrasiveness of plant material (especially grasses) will wear the tooth cusps blunter and lower as compared to non-abrasive plants which allow tooth-to-tooth wear (attrition) to maintain high occlusal relief and sharp cusps, in molar teeth that are in a similar state of wear (Fig. 2.2). Why grasses are especially abrasive on tooth enamel is still not totally understood, but whether it is because of high phytolith contents, external grit accumulating on grass leaves or even simply 
1.

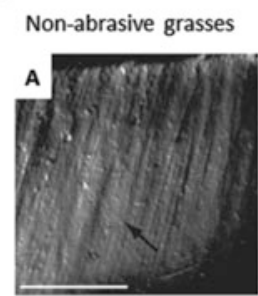

Middle MioceneAcritohippus isonesus

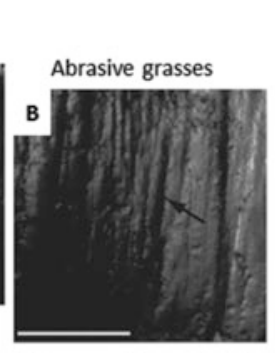

Pliocene-Equus simplicidens

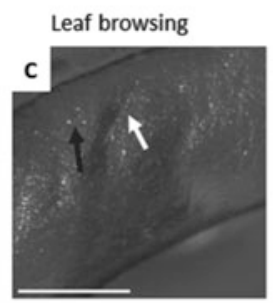

Middle MioceneMegahippussp.

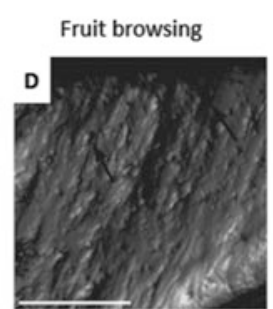

Early Miocene - Archaeohippus

2.

Selenodont and (ecto)lophodont ungulates (e.g. deer, horses, cattle) Rhinoceroses

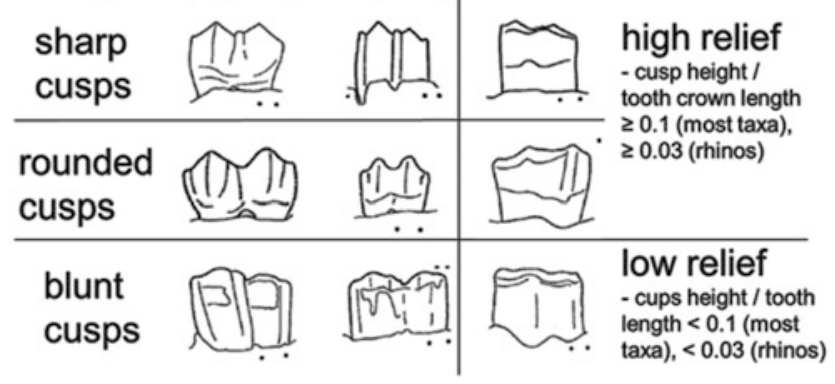

3.

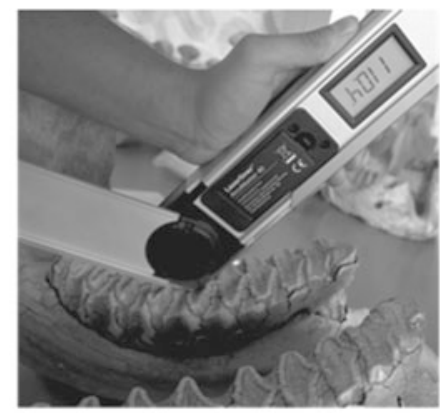

Loxodonta africana from Tsavo East, mean angle around $110^{\circ}$

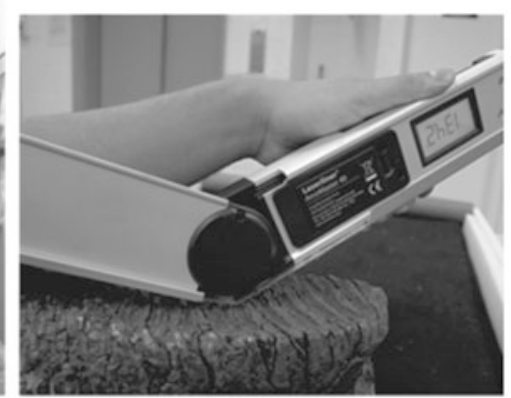

Mammuthus primigenius from Alaska, mean angle $\approx 130^{\circ}$

Fig. 2.2 Tooth wear -based dietary analysis methods. (1) Examples of microwear: more scratched microwear signal (A and B) indicates grazing and more pitted (C) browsing, whereas fruit eating (D) is indicated by gouges. Image modified from Semprebon et al. (2016a). (2) Traditional mesowear scoring. The shape of the cusps is scored as sharp, rounded or blunt, and the relief as high or low. Image modified from Fortelius and Solounias (2000). (3) Mesowear angle analysis. The relief of the worn enamel ridges of e.g., proboscidean molars can be measured as angles using a digital angle meter. Sharper angles (as for the modern African elephant, Loxodonta africana, molar here) indicate more browsing diet than blunter angles (as for a woolly mammoth, Mammuthus primigenius, molar here). Photos: Juha Saarinen, Tsavo Research Station an American Museum of Natural History. (Permits to re-use the figures have been received from the original authors and publishers) 
the coarse fibres of plant leaves (e.g., Lucas and Omar 2012; Damuth and Janis 2011; Lucas et al. 2014), the empirical basis of this observation is extensive (e.g., Fortelius and Solounias 2000; Kaiser et al. 2013; Saarinen and Lister 2016). Mesowear analysis is done by visually scoring the cusp shape as sharp, rounded or blunt and the relief (the relative height of the cusps) as high or low. When large samples of ungulate molar teeth are analysed, the mesowear scores reflect the relative amount of abrasive material (mostly grass) in the diet of the ungulate species and local populations/assemblages. The method is easy to use, it can be readily applied to fossil ungulate molars and it gives a robust signal of the abrasiveness of the diet of an herbivorous mammal over a relatively long period of its life. Blind tests have shown that the mesowear analysis based on the traditional visual observing is mostly consistent between observers (Loffredo and DeSantis 2014).

Since the introduction of the mesowear analysis (Fortelius and Solounias 2000), the method has been extended to cover lower molars of rhinoceroses (Hernesniemi et al. 2011), lower molars of ruminants (Fraser et al. 2014), marsupial teeth (Butler et al. 2014) and rodent and lagomorph teeth (Ulbricht et al. 2015). Moreover, a "mesowear ruler" with references to more detailed cusp shape categories has been used (Mihlbachler et al. 2011), and the cusp shape and relief can be transferred into univariate mesowear scores/values to facilitate statistical analyses and comparisons (e.g., Rivals et al. 2007, 2010; Saarinen et al. 2016). A further recent development is the new approach called "mesowear III", where the mesial and distal shape of the inner rather than outer enamel band of buccal cusps/lophs is analysed (Solounias et al. 2014).

\subsubsection{Extending the Mesowear Method: Mesowear Angle Analysis}

The main limitation of the traditional mesowear analysis, based on visually observing the relief and shape of the worn cusps, is that it can only be done for teeth with easily observable outer edge from which those features are easy to observe, such as the selenodont and (ecto-) lophodont molars of perissodactyls and ruminants (Fortelius and Solounias 2000). However, the principle can be extended to cover other types of tooth morphology.

Proboscideans (elephants and their fossil relatives) have specialised transverselophed or lamellar molars where the relief and shape of the worn lophids/lophs/ lamellae cannot easily be visually observed, and this is further complicated by the specialised fore-aft chewing cycle of the elephants where the lophs/lamellae meet obliquely to the direction of the lophs (Maglio 1973; Saarinen et al. 2015). However, differences in the relief of worn enamel ridges on the molar surface develop in proboscidean molars, and these are related to diet following the principle behind the mesowear analysis: increasingly abrasive foods (usually grass) wear the enamel ridges lower in relation to the softer dentine valleys in the lophs, creating lower relief on the molar surface. This relief can be measured as angles placed at the bottom of the worn dentine valleys on the molar surfaces (Saarinen et al. 2015; Fig. 2.2(3)). The blunter the angles are, the lower is the relief, indicating an 
increasingly abrasive, grass-based diet. This method has also been successfully utilised for palaeodietary analyses of xenarthrans, which do not have enamel in their teeth, but develop different patterns of occlusal relief on the worn teeth, which are similarly related to grass vs. browse (Saarinen and Karme 2017). As a result of these and other methodological developments, the mesowear analysis can now be used for palaeodietary analyses of practically all herbivorous mammals from ungulates (Fortelius and Solounias 2000; Hernesniemi et al. 2011; Fraser et al. 2014) to proboscideans (Saarinen et al. 2015), xenarthrans (Saarinen and Karme 2017), marsupials (Butler et al. 2014) and small mammals (Ulbricht et al. 2015).

\subsubsection{Stable Isotopes}

Stable isotope fractions in tooth enamel offer proxy methods for dietary analyses of several mammal groups. Values of $\delta^{13} \mathrm{C}$ and $\delta^{15} \mathrm{~N}$ isotopes differ in C3-photosynthetisising plants and C4-photosyhtetisising plants (most of which in the tropics are grasses), so they leave different isotope fractions in the teeth of herbivorous mammals eating them (Lee-Thorp and van der Merwe 1987; Cerling et al. 1997). This methodology can only be used for comparing the fractions of $\mathrm{C} 3$ and $\mathrm{C} 4$ plants in the diets, but it is useful because strong $\mathrm{C} 4$ signal reflects diets based on grasses in tropical and subtropical areas where $\mathrm{C} 4$ grasses dominate (Cerling et al. 1997). However, a limitation of this method for palaeodietary analyses is that it only reflects grazing vs. browsing more or less directly in tropical and subtropical areas where most grasses are $\mathrm{C} 4$ photosynthesising, and even there only when $\mathrm{C} 4$ grasses started to become abundant in the Late Miocene ca. 10 Ma (e.g., Cerling et al. 1997, 2015). Another limitation is that not all grasses, even in the tropics, are C4 photosynthesizing. Thus, tooth wear -based palaeodietary analyses (microwear and mesowear) are needed to evaluate feeding on $\mathrm{C} 3$ photosynthesizing grasses.

\subsection{The History of Ungulate Diets and Evolution Throughout the Cenozoic Fossil Record}

\subsubsection{Palaeocene (65-56 Ma): The Time of Archaic Ungulates, or "Condylarths"}

Grasses originated long before they became a prominent part of the diets of herbivorous mammals. The earliest fossil record of grasses dates back to Late Cretaceous, and fossilised grass phytoliths have even been discovered in the coprolites (fossil dung) of sauropod dinosaurs from the Late Cretaceous of India (Prasad et al. 2005). However, for a very long period (in most parts of the world until the Miocene, ca. 23-5 Ma), grasses were a relatively minor element of plant communities and they did not form extensive grassland ecosystems (e.g., Strömberg 2011). 
After the extinction of large non-avian dinosaurs in the Late Cretaceous mass extinction ca. $65 \mathrm{Ma}$, mammals started to diversify and fill in the ecological niches of large terrestrial animals (Alroy 1998; Smith et al. 2010; Raia et al. 2013). Global temperatures increased drastically during the Palaeocene, leading to the exceptionally warm "Palaeocene-Eocene Thermal Maximum" at the end of this epoch (Zachos et al. 2001, 2008). Consequently, tropical and subtropical forest environments were the dominant habitats globally (e.g., Strömberg 2011). Among herbivorous mammals, perhaps the most prominent event was the emergence and radiation of early ungulates, often grouped together in a paraphyletic assemblage called the "Condylarthra", which are characterised by brachydont (low-crowned) and bunodont (cusps as separate knobs) dentitions, suggesting adaptation to omnivorous, relatively generalist diets (Rose 2006). The condylarths were globally widespread during the Palaeocene, being the dominant medium- to large-sized mammals in Eurasia, North America and South America, and they ranged from small forms with weasel-like bodies (Hyopsodus) to larger, up to about sheep-sized omnivorous forms (e.g., Arctocyon and Phenacodus). Some of the later condylarths, such as Meniscotherium, show the development of increasingly lophodont (cusps elongated and fused into ridges) dentitions, suggesting increasing adaptation to browsing herbivorous diets (Williamson and Lucas 1992).

Other groups of large herbivores, probably unrelated to modern ungulates, emerged too, the ecologically most important being the pantodonts, which evolved dilambdodont (upper molars with a W-shaped ectoloph on the buccal side) or functionally bilophodont (molars with two transverse crests) dentitions suggesting adaptation to frugivorous-folivorous or browsing diets (Rose 2006). The pantodonts originated in Asia and spread to North America where they became particularly diverse, including various species ranging from relatively small (e.g., Pantolambda), to large, roughly tapir to bison-sized forms (Barylambda, Coryphodon, Titanoides) (Rose 1981, 2006; Beard 1998). Another group of large, bilophodont herbivores, the Dinocerata, emerged in Asia (Prodinoceras), and soon dispersed to North America (Rose 1981, 2006; Beard 1998). In addition, there were a couple of groups with a body build suggesting fossorial lifestyles and sturdy skulls and dentitions suggesting diets based on gritty roots and tubers. These were Tillodonta, which originated in Asia and dispersed to North America, and Taeniodonta, an endemic North American group (Lucas and Schoch 1998; Lucas et al. 1998). In South America, an enigmatic group of ungulate-like mammals called Xenungulata existed during the Palaeocene, and some of them (e.g., Carodnia) were quite large, roughly tapir-sized herbivores with bilophodont molars suitable for browsing (Rose 2006).

\subsubsection{Eocene (56-33.9 Ma): The Emergence and Radiation of Modern Mammal Lineages}

The Eocene was the longest epoch of the Cenozoic era, lasting ca. 22 million years, and drastic changes happened in mammal faunas throughout this time. Ungulates had started to diversify during the Late Palaeocene, and during the Early Eocene 
climatic optimum most of the major modern orders of herbivorous mammals emerged, including the even-toed ungulates (Artiodactyla), the odd-toed ungulates (Perissodactyla) and endemic South American ungulates (Meridiungulata). The proboscideans (Proboscidea) and hyraxes (Hyracoidea) also emerged as a result of a separate radiation of the Afrotherian ungulate-like herbivores (Paenungulata). In addition, several archaic groups of medium- and large-sized herbivorous mammals flourished especially during the Early and Middle Eocene, such as Pantodonta, Dinocerata, Tillodontia, Taeniodonta and the last archaic "condylarth" ungulates. The diversity of mammals was higher on both the species and higher taxonomic levels during the Middle Eocene than ever before or after (Janis 1993; Blondel 2001; Saarinen et al. 2014). The global climate during the Early Eocene was warmer than ever during the Cenozoic, and subtropical forest environments reached very high latitudes (e.g., Erlebe and Greenwood 2012). During the latter part of the Eocene, the global climate started to cool, but still remained warm and humid, much warmer than later during the Cenozoic (Zachos et al. 2001, 2008). Grasses were a rare component of the floras globally throughout the Eocene. No specialised grazers have been discovered from the Eocene. Nevertheless, there was variation in the diets of the herbivorous mammals and in general there was a shift towards folivorous browsing diets throughout the Eocene among many lineages that started as omnivores or frugivores.

\subsubsection{Eurasia}

The climate during the Early and Middle Eocene was warm and humid, and global sea level was high, making Europe a large archipelago which had connections to North America and Asia. The mammal fossil assemblages of this time, such as that from the locality of Abbey Wood, UK, indicate palaeoenvironments essentially similar to modern tropical rainforests (Hooker and Collinson 2012). There was a change in European large herbivore faunas at the beginning of the Eocene when some taxa, especially the large bilophodont pantodont Coryphodon eocaenus, arrived from North America (Hooker and Collinson 2012). This species was the largest browser in the Early Eocene European forests. It shared its habitat with some late surviving condylarths, which had bunodont dentitions and probably omnivorous or frugivorous diets, such as Hyopsodus and Phenacodus, another newcomer from North America. However, the Early Eocene large herbivorous mammal faunas were dominated by early perissodactyls, including early and small horses (Equidae) such as Pliolophus vulpiceps, palaeotheres (Eurasian relatives of horses) such as Hyracotherium leporinum, large tapiromorphs with bilophodont dentition known as lophiodonts (genus Lophiodon) and other smaller tapiromophs such as Hyrachyidae (e.g., Blondel 2001). The dentition of most of these early perissodactyls, together with the less abundant early artiodactyls represented by Diacodexis and other forms derived from it, was brachydont and still predominantly bunodont or buno-lophodont, suggesting that they were largely frugivores (Blondel 2001). The key to why the early perissodactyls were more diverse and abundant than 
the early artiodactyls is probably the difference in the evolution of digestive systems in these major ungulate groups: the perissodactyls developed an enlarged caecum and colon for digesting plant material in the Early Eocene which made them more effective as browsers of leaves than the artiodactyls which probably had not yet developed an effective fermenting system (Janis 1976).

Middle Eocene palaeobotanical evidence suggests that the palaeoenvironments of Europe were similar to modern tropical rainforests (Collinson and Hooker 1987; Collinson 1992) and rich fossil sites, such as the exceptionally preserved assemblage of fossil plants, invertebrates, fish, reptiles, amphibians, birds and mammals from Messel, Germany, support that interpretation. The Middle Eocene large herbivorous mammal faunas from Europe were strongly dominated by what appear to be quite unspecialised frugivorous-folivorous and browsing perissodactyls, such as the buno-lophodont palaeotheriids (e.g., Propalaeotherium, Palaeotherium and Plagiolophus) and the large bilophodont lophiodontids (Lophiodon). Also one genus of early true horses (Eurohippus) is known from sites such as Messel, Germany. A frugivorous-folivorous diet has been confirmed for the palaeothere Propalaeotherium from Messel and Geiseltal by analysis of preserved stomach contents (Sturm 1978; Wilde and Hellmund 2010). However, the diversity of artiodactyls increased drastically as well, with many new lineages emerging, and browsing forms started to dominate over omnivorous and frugivorous forms (Blondel 2001). Among these were the first selenodont ungulates of the families Xiphodontidae and Amphimerycidae.

During the Late Eocene the environments of Europe changed somewhat as the result of the climatic cooling but they were still dominated by evergreen forests, albeit these were subtropical rather than tropical (Collinson and Hooker 1987; Collinson 1992). The herbivorous mammal faunas changed too and there was a shift from frugivorous-folivorous diets to increasingly specialised folivorous browsing in both perissodactyls and artiodactyls. The perissodactyls were dominated by browsing forms (e.g., large palaeotheriids such as Palaeotherium magnum), whereas some earlier groups such as the lophiodonts became extinct. True horses (Equidae) also vanished from Eurasia at this time, retuning much later in the Early Miocene with the dispersal of anchitherine equids from North America. The overall diversity of perissodactyls declined and artiodactyls became the dominant ungulates in Europe during the Late Eocene (Blondel 2001). New types of artiodactyls appeared, such as the small-sized selenodont cainotheres (Cainotheriidae) with probably frugivorous-folivorous diets, and the large-sized buno-lophodont anoplotheriids (Anoplotherium), which have been interpreted as a specialised, bipedally highbrowsing animals somewhat similar in feeding ecology to the later chalicotheriid perissodactyls (Hooker 2007).

The Eocene palaeoenvironments of Eastern and Southern Asia were mostly dominated by forest and woodland palaeoenvironments (e.g., Zaw et al. 2014), and this is reflected in the mammal faunas which were dominated by diverse large browsers, especially perissodactyls (Wang et al. 2007). In Central Asia more arid environments, with drought-adapted shrubs, were present as early as in the Palaeocene, but those were still mixed with forest and woodland vegetation (Jacobs 
et al. 1999). Several major groups of ungulates originated in Asia during the Early and Middle Eocene and soon migrated to North America, and somewhat later, at the beginning of the Oligocene, to Europe. Among the perissodactyls, these were the amynodonts (Amynodontidae) and hyracodonts (Hyracodontidae), which were early relatives of rhinoceroses, and eomoropids which were early relatives of chalicotheres. True rhinoceroses (Rhinocerotidae) emerged during the Late Eocene in Asia and North America, with either of these continents considered to be the area of origin for that group (Prothero et al. 1989).

Even more important evolutionary radiations occurred among the artiodactyls in Asia during the Middle Eocene, with the emergence of several major groups, including the anthracotheres (Anthracotheriidae), a group of suiform artiodactyls with buno-selenodont dentition, related to later hippopotamids, with typically amphibious lifestyles (Lihoreau and Ducrocq 2007). Their dentition indicates diets based predominantly on unspecialised consumption of fruits, leaves and other plant material (Blondel 2001), but more specific palaeodietary analyses would be needed to further confirm this. Another group of suiforms was the large-sized, fully terrestrial and relatively cursorial entelodonts (Entelodontidae), which were characterised by large skulls and dentitions which comprised carnivore-like canines, strong triangular premolars and bunodont molars (Foss 2007). This kind of dentition indicates omnivorous diet with probably a large component of animal carcasses (Boardman and Secord 2013). The earliest entelodonts was the relatively small Eoentelodon from the Middle Eocene of China. Finally among the radiation of suiform artiodactyls was also the ancestral group of pigs (Suidae) and peccaries (Tayassuidae) known as Palaeochoeridae, with bunodont teeth and probably omnivorous diets (Liu 2001).

Perhaps most importantly regarding later Cenozoic mammal faunas, the ruminants originated in Asia during the Middle Eocene, being represented by small species with incipiently selenodont dentitions, such as Archaeomeryx and Archaeotragulus (Métais et al. 2001, 2005).

\subsubsection{North America}

During the Early Eocene (Wasatchian and Early Bridgerian), North America had a connection with the European archipelago, and, as a result, they shared many similar mammal taxa (Rose 1981; Janis 1993). The global temperatures were extremely high and the environments of North America were dominated by tropical forests and woodlands (Zachos et al. 2008; Strömberg 2011). Even arctic areas were covered by subtropical forest, as shown by the rich fossil assemblage containing, among others, fossil plants, fish, mammals, turtles and alligators from the High Arctic of Canada (Erlebe and Greenwood 2012). The large browsing bilophodont pantodont Coryphodon was widely distributed in North America, from where it dispersed to Europe. The ungulate faunas, indicated especially by the rich fossil assemblage from the Green River Formation, Wyoming, were dominated, for the first time, by early horses (Equidae) represented by several small species with very low-crowned, bunolophodont molars (Rose 1981). Their dental morphology indicates a dietary 
adaptation to feeding on fruit and browse (e.g., Janis 2007), and mesowear analysis indicates a diet that was more abrasive than in later browsing anchitheriine equids, also suggesting the consumption of fruits with hard seeds (Mihlbachler et al. 2011). Originally they were all included in the genus Hyracotherium, but actually comprise several genera and species such as Eohippus, Sifrihippus and Protorohippus, possibly including taxa more closely related to the European palaeotheres (Froehlich 2002). The next most abundant taxa, which had been the dominant ungulates in the Late Palaeocene, were the condylarths Phenacodus, Ectocion and Hyopsodus, of which Phenacodus and Hyopsodus were also present in Europe. The first artiodactyls were represented by the small diacodexeids with unspecialised bunodont dentition, such as Diacodexis and Bunophorus (Rose 1981). In addition to the abundant early equids, the perissodactylan radiation in North America included early tapiromorphs (e.g., Homogalax) and early brontotheres (Eotitanops borealis), which were small compared to the later very large forms of their clades and had relatively simple buno-lophodont dentitions and probably rather unspecialised fruit and browse diets. Eotitanops was replaced by a somewhat larger (tapir-sized) but otherwise quite similar genus Palaeosyops during the latter Early Eocene. As in Europe, most of these early herbivores were probably largely frugivore-folivores. The dinoceratans dispersed from Asia to North America during the Early Eocene and were represented first by the prodinoceratid Probathyopsis and later by the larger uintathere Bathyopsis. Their bilophodont dentitions indicate browsing diets (Rose 2006). Tillodonts of the genus Esthonyx were also present and may have been fossorial animals. Their heavy tooth wear has been interpreted to have resulted from grit associated with roots and tubers and they may have used their enlarged incisors to pull roots from the ground, as indicated by wear marks (Lucas and Schoch 1998).

Middle Eocene large herbivorous mammal faunas from North America were extremely diverse, including many lineages of early perissodactyls (equids, brontotheriids, hyracodonts, amynodonts, eomoropids and various tapiromorphs) and artiodactyls together with archaic groups of roughly ungulate-like herbivores with uncertain phylogenetic relationships, such as Tillodontia and Dinocerata (e.g., Janis 1993; Gunnell et al. 2009). Palaeoenvironmental proxy data indicates the dominance of subtropical-tropical forest environments, although some continental inland areas were starting to change towards drier and more open woodland conditions, although grasses were largely absent in all the environments (Strömberg 2011). The equids were still represented by small archaic "hyracotheres" with buno-lophodont dentitions and frugivorous-folivorous diets, such as Orohippus and Epihippus, but they were less diverse than in the Early Eocene. In contrast, the brontotheriids radiated into several medium- to large-sized genera, such as Palaeosyops, Telmatherium, Mesatirhinus, Metarhinus, Dolichorhinus and Diplacodon. The brontotheres had brachydont, buno-lophodont teeth with a prominent ectoloph, and typically high and sharp mesowear signals, indicating browsing diets (Mihlbachler 2008; Saarinen, own observations). Other perissodactyls included various tapiromorphs (e.g., Homogalax, Helaletes and Hyrachyus) and early relatives of later chalicotheriids (a group of highly specialised clawed perissodactyls) 
known as eomoropids (Eomoropus). These taxa also had buno-lophdont or incipiently bilophodont molars and were most likely quite unspecialised browsers of fruits and leaves. A new group of perissodactyls, the rhinocerotoid amynodonts arrived from Asia, represented by the genus Amynodon, which had more specialised lophodont molars roughly similar to those of true rhinoceroses and were most likely browsers (Wall 1998). However, unlike most early rhinocerotoids, some later amynodonts during the Late Eocene-Early Oligocene (Metamynodon in North America and Cadurcotherium in Eurasia), evolved more hypsodont molars, but whether this was an adaptation to feeding on gritty or particularly tough plants is, as yet, not well understood (Prothero et al. 1986; Blondel 2001). On the other hand, some late amynodonts, such as Cadurcodon, apparently had a tapir-like proboscis, suggesting a specialised browsing rather than grazing diet (Prothero et al. 1986).

Among the artiodactyls, three major new groups endemic to North America emerged: the merycoidodonts (oreodonts) and agriochoerids (Oreodontoidea) represented in the Middle Eocene by Protoreodon, the protoceratids (Protoceratidae) represented by Leptomeryx and Leptoreodon and camels (Camelidae) represented by Protylopus. These lineages of selenodont artiodactyls were probably all part of the Tylopoda, of which only camels survive today, and became the dominant groups of large herbivorous mammals in North America during the Oligocene. The last condylarths were represented by the small-sized, squirrel-like genus Hyopsodus. The dinoceratans were represented by advanced uintatheriids, which evolved into large-sized taxa such as Uintatherium and Eobasileus. Some of these were heavily built, megaherbivore-sized (over a ton in body mass) herbivores, and they had robust skulls with bony horns, long and blade-like upper canines and bilophodont molars suitable for leaf browsing (Rose 2006). The presumably root digging tillodonts were represented by the largest, about bear-sized genus Trogosus.

Unlike in Europe but similarly to Central Asia, there was a drastic change in the Late Eocene in North America towards substantially more open environments, at least in what is today the western inland of USA (Strömberg 2011). However, the paleoenvironments were still predominantly open woodlands and shrublands, with grasses being present but not yet forming extensive grassland environments (Strömberg 2011). These environments supported diverse herbivore communities with predominantly browsing diets (Boardman and Secord 2013; Mihlbachler and Solounias 2006; Mihlbachler et al. 2011). Probably the best fossil Late Eocene fossil record in North America comes from the famous White River Badlands of western USA, where the deposits range from Late Eocene to Early Oligocene and record a change in climate, vegetation and mammal assemblages across the EoceneOligocene boundary. The large herbivorous mammal fauna included the latest and very large-sized brontotheres (Megacerops), amynodonts (Metamynodon), hyracodonts (Hyracodon), early true rhinoceroses (Trigonias and Subhyracodon) early anchitheriine equids (Mesohippus), anthracotheres (Aepinacodon, Elomeryx), entelodonts (Archaeotherium), peccaries (Perchoerus), early small camels (Eotylopus and Poebrotherium), agriochoerids (merycoidodont-like selenodont artiodactyls represented by Agriochoerus), merycoidodonts (Oreonetes, Bathygenys and Merycoidodon), protoceratids (Pseudoprotoceras) and early traguloid ruminants 
(Hypertragulus and Leptomeryx). Mesowear analysis indicates that the Late Eocene merycoidodonts had somewhat more abrasive diets than the very browse-dominated diets in the abundant Early Oligocene merycoidodonts, reflecting possibly a higher level of mixed-feeding, or feeding on leaves and fruits with seeds (Mihlbachler and Solounias 2006). The protoceratids, a camel-related group of selenodont artiodactyls, had tooth wear typical for browsers (Janis 1982). The small anchitheriine horse Mesohippus had more specialised lophodont molars than its "hyracothere" predecessors, and mesowear analysis indicates that it had a diet based largely on dicotyledonous leaves, rather than the more generalised diet of the "hyracotheres" based on leaves and fruit with abrasive seeds. Based on various analyses of dental mesowear, microwear, morphology and stable isotopes, most of the rest of the ungulate fauna were also browsers, but some such as the early rhinoceroses Subhyracodon and Trigonias, the anthracothere Aepinacodon and the early camel Eotylopus show some indication of browse-dominated mixed-feeding (Boardman and Secord 2013). Based on microwear analyses, the bunodont peccary Perchoerus was a hard object browser and the entelodont Archaeotherium was a high-abrasion omnivore (Boardman and Secord 2013). Based on stable isotope analyses, the large browsing brontothere Megacerops and the peccary Perchoerus were feeding in more closed habitats, and the equid Mesohippus and the agriochoerid Agriochoerus in more open habitats, than the rest of the cohabiting fauna (Boardman and Secord 2013).

\subsubsection{Africa}

Much less is known about the Eocene mammal faunas and palaeoenvironments of Africa than those of Eurasia and North America. The palaeoenvironments were mostly dominated by forests, woodlands and marshes, although there are indications of more open environments and presence of (possibly wetland) grasses in the Middle Eocene of Western Africa (Jacobs et al. 2010) and Late Eocene of Northern Africa (Strömberg 2011). The latest Palaeocene-earliest Eocene deposits of Ouled Abdoun basin in Morocco comprise enigmatic condylarth-like mammals (Abdounodus and Ocepeia) and the earliest proboscideans (Eritherium, Phosphatherium and Daouitherium). The El Kohol deposits from Algeria, slightly later Early Eocene in age, contain the larger early proboscidean Numidotherium and the basal hyracoid Seggeurius. Nothing much is known about the diets of these early African large mammals, but their brachydont, bunodont dentitions indicate omnivorous or frugivorous feeding ecologies, the only exception being Numidotherium, which shows bilophodont molars better suited for processing folivorous browse (Rasmussen and Gutiérrez 2010; Sanders et al. 2010).

The best Eocene mammal record from Africa comes from the Late Eocene and Early Oligocene Fayum Beds from Egypt, which will be discussed further in the next section for the Oligocene. 


\subsubsection{South America and Australia}

Also South America and Australia remain relatively enigmatic in terms of herbivorous mammal diets during the Eocene. South American palaeoenvironments were dominated by tropical to temperate forests, and grasses were sparse, although fossil phytoliths indicate the presence of grasses in Patagonia (Strömberg 2011). Early and Middle Eocene palaeobotanical records from Australia indicate rainforest and sclerophyllous forest environments in northwestern, central and southeastern parts of the continent (Strömberg 2011). During the Late Cretaceous and earliest Cenozoic there was a land connection between these continents, which enabled some early marsupials to colonise Australia from South America (Woodburne and Case 1996).

The endemic South American ungulates (Meridiungulata) diversified during the Eocene into various species of medium- and large-sized notoungulates and litopterns, which had lophodont dentitions resembling those of perissodactyls (Rose 2006). Some of the notoungulates had already evolved hypsodont cheek teeth earlier than the ungulates on other continents, suggesting perhaps a diet based on relatively fibrous plants, or the accumulation of volcanic ash on the plants they were feeding on, rather than feeding on grasses which were scarce in the still quite heavily forested palaeoenvironments (Janis 1993; Ortiz-Jaureguizar and Cladera 2006; Reguero et al. 2010; Strömberg 2011; Strömberg et al. 2013).

We know next to nothing about the diets and dietary adaptations of Eocene mammals in Australia. A probable condylarth ungulate, Tingamarra porterorum, from the Early Eocene of Queensland (Godthelp et al. 1992) had buno-lophodont molars indicating perhaps a frugivorous-folivorous diet, but the fossil mammal record from Australia enables more thorough glimpses to the evolution of herbivorous mammal diets on the continent earliest from Late Oligocene onwards.

\subsubsection{Oligocene (33.9-23 Ma): A Time of Global Climatic Cooling}

The Oligocene is characterised by a cooling of global climate which started during the Late Eocene, after the globally extremely warm "greenhouse" climate of the Early and Middle Eocene (Zachos et al. 2001, 2008). This cooling trend also resulted in the Antarctic glaciation. However, global temperatures were still much higher than in the late Neogene, especially Pleistocene, and most of the globe was still dominated by subtropical and temperate forest and woodland environments, although more arid and open environments developed e.g., in Central Asia and central North America, and C4 grasses originated, possibly in response to a significant drop in atmospheric $\mathrm{CO}_{2}$ content (Vicentini et al. 2008; Strömberg 2011). Herbivorous mammal faunas across the globe still consisted predominantly of browsers. However, in the Late Oligocene, some semi-open, grassy woodlands occurred in South America, e.g., in Salla, Bolivia (Strömberg 2011), where some 
of the earliest grazing ungulates and mylodontid sloths occurred (Croft and Weinstein 2008; Shockey and Anaya 2011).

\subsubsection{Eurasia}

Europe remained predominantly forested throughout the Oligocene, although the vegetation changed towards more temperate conditions (Strömberg 2011). The beginning of the Oligocene in Europe was marked by a turnover of the mammal faunas known as the "Grande Coupure", where new mammal taxa migrated from Asia to Europe as the result of marine regression that opened a land connection between Europe and Asia. There are rich European Early Oligocene mammal assemblages, e.g., from Ronzon and Phosphorites du Quercy, France, and Bouldnor Formation, UK, and Late Oligocene assemblages such as La Milloque, France, and Rickenbach, Switzerland. Among the most prominent newcomers were early ruminants with body sizes similar to modern tragulids and moschids, such as Gelocus, Bachitherium, Amphimeryx, Lophiomeryx and Amphitragulus, including musk deer -like genera, such as Dremotherium and Bedenomeryx. Other abundant ungulate groups include anthracotheres (e.g., Anthracotherium, Bothriodon, Elomeryx and Microbunodon), entelodonts (Entelodon), cainotheres (Cainotherium, Cainomeryx), xiphodonts (Xiphodon), early suids (e.g., Palaeochoerus), the last palaeotheres (Plagiolophus), late amynodonts and hyracodonts (relatives of rhinos, represented by Cadurcotherium and Egyssodon, respectively), true rhinoceroses (Ronzotherium) and tapirs (Protapirus). As far as we know, most of these medium and large-sized herbivorous mammals were browsers and had brachydont dentitions, but some of the early ruminants might already have started to shift towards mixed-feeding, as indicated by tooth wear studies (Novello et al. 2010). Moreover, the amynodont Cadurcotherium had evolved more high-crowned molars, but not much is known about its diet, although feeding on plants with grit or phytoliths in more open environments has been suggested (Blondel 2001).

Anthracotheres were a group of eco-morphologically pig or hippo-like ungulates with a tendency for amphibious lifestyles, characterised by elongate skulls and peculiar buno-selenodont molars which were brachydont and had large, separate cusps, but the cusps were elongated into longitudinal, crescent-shaped structures. They had originated in Southern Asia during the Eocene and migrated to Europe during the Eocene-Oligocene transition. Their closest living relatives are whales and hippopotami (Boisserie and Lihoreau 2006). The most likely diet of the European Oligocene anthracotheres has been interpreted as mixed fruit and browse based on the tooth morphology (Blondel 2001), but further palaeodietary analyses would be needed for more precise information about their diets and feeding ecology. The entelodonts, represented in the European Oligocene by the genus Entelodon, were by this time already very large (cow to bison-sized), fully terrestrial suiform artiodactyls with brachydont, bunodont molars and strong triangular premolars, indicating an omnivorous/scavenging diet (e.g., Blondel 2001). The early true pigs (Suidae) were small and also had bunodont teeth typical of omnivores. 
The early ruminants had brachydont, selenodont molars and they ranged from small forms which probably had rather unspecialised frugivorous-folivorous diets (e.g., Amphimerycidae) to somewhat larger forms with more specialised folivorous browse diets, such as Bachitherium, Bedenomeryx and Dremotherium (Blondel 2001). The browsing ruminants most probably had partially developed foregutfermenting stomachs (because those are present in all modern ruminants in some form) and were ruminating (Janis 1976; Blondel 1998, 2001). Cainotheres and xiphodonts, the small non-ruminant, tylopod-related selenodont artiodactyls, probably had rather unspecialised fruit and browse-based diets (Blondel 2001). Most of the perissodactyls in the Oligocene of Europe were browsers ranging from frugivorous-folivorous to folivorous, characterised by lophodont, brachydont dentitions (e.g., Blondel 2001; Joomun et al. 2008). Some of them, such as the palaeothere Plagiolophus and the amynodont Cadurcotherium, had more high-crowned cheek teeth, suggesting a diet based on more abrasive, perhaps fibrous browse (Blondel 2001).

In Central Asia climate became drier at the Eocene-Oligocene transition ca. $34 \mathrm{Ma}$, as indicated among other lines of evidence by the beginning of Aeolian dust accumulation in the Chinese Loess Plaetau (Sun and Windley 2015). The palaeoenvironments in Central Eastern Asia were a mosaic of wooded and drier, more open environments, where the vegetation probably consisted of abundant shrubs, whereas grasses were still scarce (Métais et al. 2003; Prothero 2013). There was a turnover in the Eastern Asian mammal faunas from the brachydont, perissodactyl-dominated fauna of the Eocene to faunas dominated by hypsodont lagomorphs and rodents in the Oligocene (Wang et al. 2007). This has been interpreted as further evidence for the spread of arid, open habitats. In Southern Asia, the paleoenvironments remained dominated by forests and woodlands, with rare grasses (De Franceschi et al. 2008).

The Asian Oligocene large mammal faunas were largely similar to the European ones in taxonomic composition, comprising anthracotheres (e.g., Anthracotherium), entelodonts (Paraentelodon), suoids (Sanitherium, Hyotherium) and early ruminants (e.g., Gelocus, Lophiomeryx), and abundant perissodactyls comprising hyracodonts (Egyssodon, indricotheres), amynodonts (Cadurcodon), true rhinoceroses (Epiaceratherium) and tapirs (Colodus) as well as the clawed chalicotheres (Schizotherium) (Wang 1992; Métais et al. 2003, 2009; Orliac et al. 2010; Prothero 2013). They mostly had brachydont dentitions and browsing diets, but a rare hypsodont, small (duiker-sized) bovid-like ruminant (Palaeohypsodontus) was present in China and Pakistan, suggesting an adaptation to feeding on abrasive, perhaps particularly fibrous plants (Métais et al. 2003).

One peculiar aspect of the Oligocene Asian faunas are the giant hyracodonts (rhino relatives) known as indricotheres, which evolved into some of the largest land mammals (e.g., Paraceratherium, Indricotherium and Dzungariotherium). They had lophodont, brachydont dentition typical of rhinoceroids and they were browsers (as shown by mesowear and stable isotope results), probably feeding from the canopy level of trees (Prothero 2013). During the Oligocene another major group of perissodactyls that occurred in Eurasia was the chalicotheres (Chalicotheriidae), a 
group of peculiar tapiromorphs with muscular bodies, elongate forelimbs, claws instead of hooves, relatively small skulls and brachydont, buno-lophodont dentition (Coombs 1978). During the Oligocene the chalicotheres were represented by small to medium-sized species of the genus Schizotherium. Studies of tooth mesowear and microwear support the traditional view based on tooth morphology that the chalicotheres (at least during the Miocene) were browsers feeding on leaves, but also included hard objects such as seeds or bark in their diet (Semprebon et al. 2011).

\subsubsection{North America}

The North American Oligocene (Orellan, Whitneyan and early Arikareean) faunas were dominated by the merycoidodonts (Merycoidodon, Miniochoerus, Eporeodon, Leptauchenia and Merycochoerus), with body sizes ranging from the about mouse deer-sized Miniochoerus to the about tapir-sized Merycochoerus (Lander 1998; Stevens and Stevens 2007; Janis 2008). All of them had selenodont molars, but some leptaucheniids such as Sespia evolved hypsodont molars earlier than most other groups of North American ungulates (Mihlbachler and Solounias 2006). Dental mesowear analysis indicates that the merycoidodonts had predominantly browsing diets in Early Oligocene, but shifted towards increasingly mixed-feeding diets during the Late Oligocene (Mihlbachler and Solounias 2006). The most abundant North American Early Oligocene mammal record comes from the famous White River Badlands, with the fossiliferous sediments spanning from Late Eocene to Early Oligocene, demonstrating some changes in the faunal composition, e.g., the extinction of the large browsing brontotheriid perissodactyls. The paleoenvironment of the Oligocene Badlands have been interpreted as semi-open woodlands and shrublands, roughly similar perhaps to the contemporaneous East Asian ones (Mead and Wall 1998; Strömberg 2011). The camels were represented in the Oligocene by small species such as Poebrotherium wilsoni, and the protoceratids by the genus Protoceras. The camels were mostly browsers, but Poebrotherium was a mixed-feeder of browse and grass, as indicated by dental mesowear and microwear (Semprebon and Rivals 2010). Protoceras was a folivorous browser with a long muzzle (Janis 1982; Prothero 1998). Many taxa of medium-sized to large herbivorous mammals were shared between the Late Eocene and Early Oligocene, such as the entelodonts (e.g., Archaeotherium), anthracotheres (Elomeryx), peccaries (Perchoerus) and the agriochoerid Agriochoerus, retaining similar diets as during the Late Eocene (Boardman and Secord 2013). However, a new taxon was the tapir Colodon, a newcomer from Asia, which was a browser occupying more closed environments in the Early Oligocene Badlands than the other ungulate taxa (Boardman and Secord 2013). Some taxa, such as the early traguloid ruminant Leptomeryx, probably occupied more open environments in the Early Oligocene than in the Late Eocene, but retained a browsing diet (Zanazzi and Kohn 2008).

The browsing anchitherine equid Mesohippus was also present together with a new, slightly larger sized genus Miohippus. Dental mesowear analysis indicates that they had low-abrasive browse diets throughout the Oligocene (Mihlbachler et al. 
2011). The hyracodonts of the genus Hyracodon, similar in size to early horses, were browsers of tough vegetation in open floodplain and shrubland environments, whereas the true rhinoceroses of the genus Subhyracodon were browsers or mixed-feeders in more wooded, riparian environments (Mead and Wall 1998). In addition, the more hypsodont amynodont Metamynodon was present (Prothero et al. 1986).

\subsubsection{Africa}

The Oligocene fossil mammal record from Africa is quite scarce and it has large temporal and spatial gaps. The known palaeoenvironments were mostly forests and swamps (Strömberg 2011; Noret et al. 2012; Jacobs et al. 2010). The best record comes from the famous Late Eocene to Early Oligocene deposits of Fayum, Egypt, where the large herbivorous mammal fauna mainly consisted of hyracoids, anthracotheres, embrithopods and proboscideans (Werdelin and Sanders 2010). The hyraxes (Hyracoidea) were the most abundant and diverse group of large herbivores, ranging from relatively small forms (e.g., Saghatherium) to long-legged and slender (Antilohyrax), to large (Megalohyrax) and even giant, megaherbivoresized (Titanohyrax) forms. However, all of these hyracoids had relatively similar brachydont, buno-lophodont or lophodont dentitions resembling those of perissodactyls and they all were probably browsers on various kinds of vegetation (Rasmussen and Gutiérrez 2010). Embrithopods were another group of herbivorous afrotherians, and they were represented in the Early Oligocene of Fayum by the rhinoceros-sized Arsinoitherium zitteli characterised by a pair of large bony nasal horns and robust bilophodont molars with relatively thin enamel. Arsinoitherium has remained a rather enigmatic taxon in terms of diet, but what little is known indicates that they were browsers feeding perhaps in relatively open habitats (Noret et al. 2012). Artiodactyls were represented in Africa at this time only by the anthracotheres (e.g., Bothriogenys), which were roughly hippo-like, amphibious herbivores with brachydont dentition and probably browse-based diets, similarly to their relatives in Eurasia and North America.

Fossil proboscideans from Fayum comprise a diverse group of large herbivores. The largest of the Fayum herbivores was the advanced numidotheriid proboscidean Barytherium, an Asian elephant-sized herbivore with a bulky and robust skull indicating the presence of a proboscis, small tusks in upper and lower jaw, and brachydont, bilophodont molar teeth with morphology and tooth wear suggesting a browse-based diet (Sanders et al. 2010). Another group of early proboscideans were moeritheres (Moeritherium lyonsi and M. trigodon), roughly pig-sized animals with peculiar low and long, barrel-like bodies and small, flat heads with incipiently tusklike incisors and brachydont, bunodont/bilophodont cheek teeth suitable for browsing (Sanders et al. 2010). Finally palaeomastodonts (Palaeomastodon and Phiomia), the early relatives of elephantoids (mammutids, gomphotheres and elephants), were present. They were megaherbivore-sized animals similar to, although slightly smaller than, the later gomphotheriid proboscideans (among which the true 
elephants later originated), with already well-developed trunks, relatively long and low skulls, long mandibular symphyses, well-developed upper and lower tusks and bunodont cheek teeth suitable for processing various kinds of food from fruits and seeds to leaves (Sanders et al. 2010).

The best Late Oligocene African large mammal record comes from Chilga, Ethiopia (Sanders et al. 2004; Noret et al. 2012; Jacobs et al. 2010). It shows a fauna largely similar to that of the Early Oligocene Fayum deposits and consists of hyracoids (Pachyhyrax, Bunohyrax, Megalohyrax) embrithopods (Arsinoitherium giganteum) and proboscideans (Palaeomastodon, Phiomia, Chilgatherium and Gomphotherium). Stable isotope analyses indicate that all these large herbivores had essentially browse-based diets, but Arsinoitherium and the hyracoids were feeding in more open habitats than the proboscideans (Noret et al. 2012). Overall the paleoenvironment has been interpreted as heavily forested (Noret et al. 2012). Palaeomastodon and Phiomia were essentially similar and probably had similar kinds of diets as their predecessors in Fayum. Chilgatherium represents a new kind of proboscidean, the deinotheres (Deinotheriidae), which seem to have evolved from a moerithere-like ancestor (Sanders et al. 2010). The brachydont, bilophodont cheek teeth of Chilgatherium, with sharp-angled mesowear also typical of later deinotheres, indicate folivorous browsing diet. The earliest gomphothere (Gomphotherium sp.) comes from Chilga, and it had bunodont cheek teeth only slightly more derived than those of the palaeomastodonts. It probably consumed many kinds of dietary items from fruits and seeds to leaves, and would likely have had more diverse diet than the probably mostly folivorous browsing Chilgatherium. This dietary niche partitioning between the specialised browsing deinotheres and the often dietary more flexible elephantoids (gomphotheres and later elephants) continued until the extinction of the deinotheres during the Plio-Pleistocene as indicated by dietary proxy studies (Calandra et al. 2008; Cerling et al. 1999).

\subsubsection{South America}

In South America, the Oligocene palaeoenvironments comprised mostly forests and woodlands, but some localities, such as the Late Oligocene deposits from Salla, Bolivia, indicate open, grassy environments (Strömberg 2011; Croft and Weinstein 2008). Based on dental mesowear analysis, the endemic South American ungulates (notoungulates) from Salla were mixed-feeders with a large component of grasses in their diet (Archaeohyrax and Federicoanaya) or specialised grazers (Trachytherus) (Croft and Weinstein 2008). They are, therefore, possibly among some of the earliest evidence of primarily grazing mammals in the fossil record. Interestingly, tooth wear also suggests that the early mylodontid sloth Paroctodontotherium calleorum from Salla was a grazer, as were later mylodontids (Shockey and Anaya 2011). However, unlike the Salla notoungulates and sloths which had hypsodont dentitions, the large pyrotheriid ungulate Pyrotherium from Salla had brachydont, bilophodont molars and C3-dominated stable carbon isotope values indicating more likely a browsing $\operatorname{diet}$ (MacFadden et al. 1994). Also, Late Oligocene leontiniid notoungulates, such as 
Fredericoanaya from Salla, still had brachydont dentitions and probably browsebased diets (Croft 2016).

\subsubsection{Australia}

The earliest comprehensive record of a fossil herbivorous mammal fauna from Australia come from the Late Oligocene deposits of Riversleigh in Queensland, and Southern Australia (Archer et al. 1989; Travouillon et al. 2009; Janis et al. 2016). The palaeoenvironments of those faunas have been interpreted as relatively open forests (Travouillon et al. 2009; Strömberg 2011). Similar to modern and Neogene times, this Oligocene herbivorous mammal community already consisted of specialised herbivorous marsupials, including diprotodontid vombatomorphs (Neohelos), early koalas (Litokoala), potoroid kangaroos (e.g., Wakiewakie) and macropodid kangaroos (e.g., Nambaroo) (Archer et al. 1989; Travouillon et al. 2009).

Not much is known about the diets of these Oligocene herbivorous marsupials, as detailed palaeodietary analyses based on dental wear and isotopes are largely lacking. However, the brachydont, bilophodont dentition of the diprotodontid Neohelos, and the forested palaeoenvironment, indicates a browse-based diet (Archer et al. 1989; Butler et al. 2017). Based on craniodental analysis, the Late Oligocene kangaroos were mostly omnivores, but included browsing forms too, especially in the Riversleigh palaeoenvironment, and they already had specialisations to the hopping locomotion typical of later kangaroos (Janis et al. 2016). The foregut-fermenting digestion of modern macropodid kangaroos, which enabled a few of them to become grazers later during the Neogene, was however probably developing during the Oligocene (Butler et al. 2017). The Oligocene koala (Litokoala) had brachydont, selenodont molars similar to the modern koala, suggesting a browse-based diet, but it lacked several of the key cranial adaptations of the modern koala, which gradually evolved during the Neogene as a specialisation to feeding exclusively on Eucalyptus leaves (Louys et al. 2009).

\subsubsection{Miocene (23-5 Ma): From Forests to Grasslands, and the Evolution of Grazing Mammals}

The Miocene was a time of drastic changes in global climate and ecosystems, during which forest and woodland -dominated vegetation was gradually replaced, in many parts of the world, by more open, grassland or savanna-type environments (Cerling et al. 1997; Strömberg 2011). Global climate became cooler and increasingly seasonal, and in mid-latitudes increasingly dry, which favoured the spread of grasslands and eventually $\mathrm{C} 4$ photosynthesizing grasses during the later part of the Miocene (Zachos et al. 2001; Strömberg 2011). Land connection formed for the first time between Africa and Eurasia, and new connections between Eurasia and North 
America formed too, enabling migrations of major groups of herbivorous mammals between the continents. These changes were reflected in the evolution and dispersal of grazing ungulates and other large herbivorous mammals during the Miocene. Major events include the evolution of hypsodont, mixed-feeding/grazing horses (Equidae, Equinae) in North America and their dispersal to Eurasia and Africa during the Late Miocene, the evolution of deer (Cervidae) and giraffes (Giraffidae) in the Old World with brachydont dentitions and usually browse-dominated diets, the radiation of bovid ruminants (Bovidae) with increasingly hypsodont dentitions and mixed-feeding to grazing diets in the Old World, the dispersal of gomphotheriid, mammutid and deinotheriid proboscideans from Africa to Eurasia and North America during the Early and Middle Miocene, and the evolution of true elephants (Elephantidae) in Africa during the Late Miocene. Since the Miocene, grazing and mixed-feeding mammals have been abundant in open grassland and savanna-like environments, whereas the remaining closed forest environments have still been dominated by browsers and browse-dominated mixed-feeders (Gordon and Prins 2008).

\subsubsection{Eurasia}

Global temperatures had started rising again during the Late Oligocene, and the Early Miocene was relatively warm and humid, and the palaeoenvironments were dominated by subtropical and temperate forests in Europe (Zachos et al. 2001, 2008; Eronen et al. 2010a; Strömberg 2011). The ruminants increased in diversity and body size, and included, among others, early deer and bovids, which by analogue of their extant relatives possibly already hadfully developed four-chambered, foregutfermenting stomachs (e.g., Janis 1976). Among the ruminants were tragulids (Dorcatherium), moschids (e.g., Pomelomeryx), palaeomerycids (early deer-like pecorans, such as Ampelomeryx, Triceromeryx and Palaeomeryx), early deer (e.g., Procervulus, Lagomeryx and Acteocemas), and the earliest bovids (Eotragus and Pseudoeotragus). Interestingly, based on dental mesowear analysis, the earliest Miocene deer seem to have been more mixed-feeding, than the earliest bovids which were more clearly browsers, at least in the early open habitats of Spain (DeMiguel et al. 2008). Later during the Miocene the deer became more specialised browsers whereas the bovids started to diversify and occupy mixed-feeding and grazing niches. The suids were mostly represented by small and medium-sized, bunodont omnivores such as Hyotherium, Conohyus and Aureliachoerus, but included some more specialised forms such as the selenodont Sanitherium and the bilophodont Listriodon with more specialised browsing diets. In Asia there were even giant, cow-sized listriodontine suids (Kubanochoerus) during the Middle Miocene. The Oligocene anthracotheriids went extinct but another kind of anthracothere Brachyodus migrated from Southern Asia to Europe and was present there during the Early Miocene. The perissodactyls were represented by abundant rhinoceroses including the hornless aceratherines (e.g., Plesiaceratherium, Hoploaceratherium and Alicornops) and teleoceratines (Diaceratherium, Prosantorhinus and 
Brachypotherium), and the horned rhinocerotines (Lartetotherium). All of these rhinos had similar brachydont, lophodont dentitions indicating browse-based diets. However, later during the Early Miocene in Spain there were early open and arid grass-dominated environments (Urban et al. 2010) which had mammal faunas with predominantly hypsodont dentitions, including an early hypsodont elasmotherine rhino Hispanotherium. These Hispanotherium faunas are the earliest ones in Europe with hypsodontungulates, suggesting open habitat and possibly grazing/mixedfeeding diets in at least some of the species (Fortelius et al. 2002; DeMiguel et al. 2008; Eronen et al. 2010a).

The fruit, bark and browse -feeding chalicotheres (see dietary analysis based on microwear in Semprebon et al. 2011), such as Anisodon, Chalicotherium and Metaschizotherium, were also present, as well as tapirs (Paratapirus and Tapirus), which remained browsers throughout their evolutionary history. During the Early Miocene, two important migration events had a significant impact on Eurasian faunas. First, gomphotheriid, mammutid and deinotheriid proboscideans migrated from Africa, facilitated by the opening of the first important land connection between Africa and Eurasia, the so called "Gomphotherium land bridge" (Rögl 1998). Analyses of dental microwear (and mesowear, Saarinen pers. obs.) have shown that there were dietary differences between these diverse proboscideans that enabled them to share their environments: e.g., Gomphotherium in Central Europe had more mixed-feeding diet than the purely browsing Deinotherium (Calandra et al. 2008). Recent results even show the earliest indication of grass-dominated diet among the Eurasian proboscideans in the derived trilophodont gomphothere Gomphotherium steinheimense from an early arid grassland environment in the Middle Miocene of Central Asia, as shown by the analysis of phytoliths preserved in dental calculus (Wu et al. 2018). The browsing deinotheres never dispersed to North America, unlike other groups of proboscideans. The "shovel-tusked" gomphothere Platybelodon was a browser which used its lower tusks to cut plants (Semprebon et al. 2016b). The second major event was the arrival of equids in Eurasia again after a long gap since the Early Eocene, migrating from North America across Beringia. The Early and Middle Miocene equids in Eurasia were represented by the anchiteriines with brachydont, lophodont molars (Anchitherium), which had rather flexible diets ranging from browsing to mixed-feeding according to local conditions, as demonstrated by dental mesowear analyses (Kaiser 2009; Eronen et al. 2010b).

The remarkable climatic cooling and drying of the climate during the Late Miocene is reflected in drastic environmental changes in Eurasia, especially in the mid-latitudes where increasingly dry and seasonal climates led to the spread of extensive woodlands, savannas and grasslands for the first time (Cerling et al. 1997; Strömberg 2011). The most remarkable changes in the herbivorous mammal faunas include the radiation and dispersal of bovids and the dispersal and radiation of the hypsodont, grazing-adapted (but mostly mixed-feeding) hipparionine equids, which arrived from North America and spread across Eurasia ca. 11-10.5 Ma. The European large mammal faunas at this time were diverse and included both archaic forest-adapted and more derived open-adapted species. Central Europe remained wooded throughout the Late Miocene (Kovar-Eder et al. 2008), although there was a 
shift during the early Late Miocene (Vallesian) from forests to more seasonal semiopen woodland environments (Agustí and Moya-Sola 1990), that supported such large browsers as the proboscideans Deinotherium and Tetralophodon, the chalicothere Chalicotherium, rhinoceroses (e.g., Aceratherium and Dihoplus), tapirs (Tapirus), tragulids (Dorcatherium) and deer (e.g., Procapreolus and Lucentia). However, there were also mixed-feeding bovids (Miotragocerus), and the hipparionine horses (Hippotherium primigenium) had diets ranging from browsing to grass-dominated feeding (Kaiser 2004). Similarly, South Eastern Asia remained forested and was dominated by browsers, such as chalicotheres (Anisodon), tapirs (Tapirus), and browsing proboscideans such as gomphotheriids (Sinomastodon) and stegodonts (Stegolophodon).

However, in large areas over the continent, including the Mediterranean region, Western Asia, Indian Subcontinent and Eastern Asia, environments gradually changed from forests and woodlands to increasingly open savannas and grasslands (Cerling et al. 1997; Strömberg 2011). There was significant aridification in Central Asia already in Middle Miocene, where palaeobotany and mammal ecometrics indicate the presence of open grasslands (e.g., Liu et al. 2009; Tang and Ding 2013). These diverse semi-open environments were home to rich mammal faunas often collectively known as the "Hipparion"-fauna. These were characterised by diverse hypsodont three-toed hipparionine horses, ranging from large (about zebrasized) mixed-feeding forms (e.g., Hippotherium sp.) to small grazers (e.g., Cremohipparion matthewi) (Solounias et al. 2010, 2013; Bernor et al. 2014). Bovids were diverse, being mostly mesodont and mixed-feeders, such as the abundant Tragoportax sp. (Solounias et al. 2013). Many widespread bovid taxa such as Gazella sp. and Urmiatherium sp. had considerable variation in diet, ranging from browsers to mixed-feeders and sometimes grass-dominated feeders depending on local environments (Bernor et al. 2014; Eronen et al. 2014). Based on tooth wear and isotope studies, early bovines (Bovini) had diets based more heavily on grasses, they lived in more open habitats and had more hypsodont molars than the contemporaneous boselaphine bovids in the Middle Siwaliks beds of the Indian subcontinent (Bibi 2007). The rest of the Late Miocene Hipparion faunas comprised abundant rhinoceroses, including species with brachydont or mesodont, lophodont dentition typical of rhinos with browse-based diets (e.g., Acerorhinus, Chilotherium and Dihoplus) and more specialised species with more high-crowned, complex teeth and grazing diets (e.g., Ceratotherium, Iranotherium and Sinotherium), large browsing chalicotheres (Ancylotherium), giraffes ranging from browsers (e.g., Palaeotragus) to mixed-feeders (e.g., Samotherium), large bunodont suids (Microstonyx) and proboscideans such as specialised gomphotheres of the genus Choerolophodon with grass-dominated diet, as shown by dental microwear and mesowear analyses (Solounias et al. 2010, 2013; Bernor et al. 2014; Eronen et al. 2014; Konidaris et al. 2016). Because of the monsoon climate in Eastern Asia, the palaeoenvironments there were divided into south-eastern areas with more humid and wooded environments and a larger proportion on brachydont, browsing mammals (including even the last archaic anchitheriine equid Sinohippus) and southwestern inland areas with more dry, seasonal and open environments (Fortelius et al. 
2002; Passey et al. 2007). In these environments, the Hipparion horses and the hypsodont gazelle Gazella dorcadoides consumed some C4 plants (grasses), whereas deer and the mesodont and brachydont gazelles $(G$. paotehensis and G. gaudryi) were pure C3 plant (probably browse-dominated) feeders, although the isotopes do not reveal possible feeding on C3 photosynthesizing grasses (Passey et al. 2007). However, mesowear analysis indicates that the $C 3$ feeders were mostly browsers and browse-dominated feeders (Eronen et al. 2014).

\subsubsection{North America}

Drastic environmental changes in North America happened during the Early and Middle Miocene, when savanna and grassland environments started to develop there as a result of the uplift of Rocky Mountains that caused a gradual climatic drying in the western interior of the continent (e.g., Van Devender and McClaran 1995), leading to the evolution of some grazing ungulates (Janis et al. 2002, 2004; Strömberg 2011). A greater change from $\mathrm{C} 3$ photosynthesizing to $\mathrm{C} 4$ photosynthesising grasslands and from brachydont browser-dominated to hypsodont grazer-dominated ungulate faunas happened from the Middle to the Late Miocene (Janis et al. 2002, 2004; Strömberg and McInerney 2011). The Early and Middle Miocene faunas comprise a wide variety of equids, including browsing anchitheriines (e.g., Megahippus and Hypohippus), early equine equids with mesodont to hypsodont dentitions (Merychippus and Cormohipparion), rhinos (Menoceras, Diceratherium, Teleoceras, Aphelops), chalicotheres (Moropus), large entelodonts (Dinohyus), camels ranging from small gazelle-like forms (Stenomylus) to larger forms (Procamelus, Oxydactylus), moschid ruminants (Machaeromeryx and Blastomeryx), antilocaprid ruminants (Ramoceros) dromomerycine palaeomerycid ruminants (e.g., Aletomeryx) protoceratids (Syndyoceras) and diverse merycoidodonts (e.g., Merychyus, Promerycochoerus, Merycochoerus, Hypsiops and Ustatochoerus). During the Middle Miocene, proboscideans migrated from Eurasia to North America, being represented by mammutids (Zygolophodon) and gomphotheriids (Gomphotherium).

Janis et al. (2002 and 2004) noted that there was a higher diversity of browsing ungulates in the Early and Middle Miocene North American semi-open savanna-like environments than in modern savannas and later North American open environments, which indicates that these were high-productivity savanna-/grassland-type environments which do not have a modern analogue. Although the Early and Middle Miocene environments were dominated by browsers in North America, some groups notably show a shift towards increasingly grazing diets, as shown by dental mesowear and adaptations to grazing (especially an increase in hypsodonty). Among these were the first equine horses (e.g., Merychippus), which in the late Early Miocene showed a shift to mixed-feeding diets and mesodont/hypsodont dentitions, and existed alongside the (at this time larger) brachydont, browsing anchitheriine horses until the Late Miocene (Mihlbachler et al. 2011). Similarly, mesowear analysis shows that the merycoidodonts, which persisted (but were no longer a significant part of the fauna) in North America until the Late Miocene, 
shifted their diets towards increasingly grass-dominated mixed-feeding during the Early Miocene, accompanied by increasing hypsodonty in some taxa, as opposed to their completely browse-based diets in the Early Oligocene (Mihlbachler and Solounias 2006).

The Late Miocene palaeoenvironments comprised largely grasslands and savannas with diverse herbivorous mammal faunas of hypsodont equine horses (Cormohipparion, Neohipparion, Protohippus, Pliohippus, Pseudhipparion, Nannippus), camels (Aepycamelus, Megacamelus), protoceratids (Synthetoceras), dromomerycine palaeomerycid ruminants (e.g., Pediomeryx, Cranioceras), antilocaprid ruminants (Sphenophalos, Texoceros and Osbornoceros), rhinos (Teleoceras, Peraceras, Aphelops), peccaries (Prosthennops) and gomphotheriid proboscideans (Amebelodon, Rhynchotherium, Tetralophodon). Following the spread of $\mathrm{C} 4$ grasslands in North America during the Late Miocene, the ungulate faunas show a significant decline in browser diversity and the predominance of mixed-feeders and grazers (Janis et al. 2002, 2004; Mihlbachler et al. 2011). However, some of the late protoceratids had long muzzles and retracted nasals, suggesting the presence of a moose-like upper lip and possibly a similar specialised browsing lifestyle (Janis 1982; Prothero 1998). The dominant grazers were the hipparionine horses, which by this time had fully hypsodont dentitions and were all grazers or grass-dominated mixedfeeders in North America, as shown by mesowear analyses (Mihlbachler et al. 2011). Even among the dromomerycines, a group of deer-like ruminants, there was a shift in Late Miocene towards mixed-feeding in the derived cranioceratines such as Pediomeryx, as indicated by dental microwear and mesowear, despite their generally browsing morphological adaptations (Semprebon et al. 2004). Microwear and mesowear analyses show that a similar shift to increasingly abrasive, mixed-feeding occurred within the antilocaprids during the Late Miocene and Early Pliocene, accompanied with an increase in the hypsodonty of their dentition (Semprebon and Rivals 2007).

\subsubsection{Africa}

Most of what we know about the Miocene of Africa comes from the rich fossil sites from East Africa, with some important records from the Early and Late Miocene of North and South Africa. During the Early Miocene, the palaeoenvironments in East Africa were dominated by tropical forests and woodlands which largely resembled the modern West African lowland rainforests (Jacobs et al. 2010; Grossman et al. 2014). The North African site of Gebel Zelten (Libya) also indicates a palaeoenvironment dominated by forests and swamps (Grossman et al. 2014). During the Middle Miocene in East Africa the environments started to change locally, and the first C3 grass -dominated grassland environments emerged (e.g., in Maboko and Fort Ternan, Kenya), driven by seasonal changes from dry to waterlogged conditions (Retallack 1992; Retallack et al. 2002). However, more drastic changes in the environments started during the Late Miocene, when C4-photosyntesising grasses spread forming abundant, partially open grassy woodland and savanna environments 
(Cerling et al. 1997; Strömberg 2011). However, there were local differences in this pattern, for example, the Lake Turkana region in Eastern Africa got drier earlier than surrounding areas, serving as a "species factory" of mammals adapted to increasingly open grassland environments (Fortelius et al. 2016). In South Africa, the shift to C4 grasses apparently happened later, as stable isotope record indicates at least locally purely C3 conditions throughout the Late Miocene in Langebaanweg (FranzOdendaal et al. 2002).

The mammal impact of the land connection between Africa and Eurasia resulted in significant changes in the Early Miocene African herbivorous mammal faunas with the arrival of ruminants (e.g., the tragulid Dorcatherium, the early pecoran Walangania and the giraffid Palaeotragus), suids (e.g., Diamantohyus and Nguruwe), rhinoceroses (Brachypotherium, Turkanatherium, Rusingaceros, Victoriaceros) and chalicotheres (Butleria). Later, during the Middle Miocene the bovids Protragocerus and Oioceros arrived, and finally the Late Miocene saw a significant radiation of the African bovids, including such African taxa as Aepyceros (impala), cephalophines (duikers), tragelaphines (kudus and relatives), hippotragines (sable antelopes), reduncines (reedbucks and waterbucks) and alcelaphines (relatives of wildebeest and hartebeest), and Eurasian immigrants such as antilopines (e.g., Gazella) and "boselaphines" (Tragoportax). Meanwhile, the endemic afrotherian herbivores, especially proboscideans, were thriving in Africa during the Miocene. The Late Miocene saw the evolution of true elephants (Elephantidae), which soon started to replace the more archaic gomphotheres. During the Early and Middle Miocene, the large mammal faunas were dominated by browsers (e.g., Uno et al. 2011), although, based on tooth wear data, there is evidence that some gomphotheriid proboscideans were already grass-dominated feeders in the Middle Miocene C3 grasslands of East Africa (Saarinen, personal observation). Several stable isotopebased studies indicate that there was a major shift from predominantly browse-based to largely grass-based diets during the Late Miocene in Africa, following the opening of the environments and the spread of C4 grasses (Cerling 1992; Cerling et al. 1997, 1999; Uno et al. 2011). This happened in many lineages of bovids, derived gomphotheres (Anancus), elephants (Primelephas and Stegotetrabelodon), suids (Nyanzachoerus australis), rhinos (Ceratotherium), and the hipparionine horses (Eurygnathohippus), whereas giraffes and deinotheriid proboscideans retained completely browse-based diets (Uno et al. 2011). Hippos (Hippopotamidae) evolved in Africa from their anthracotheriid ancestors during the Middle Miocene (Boisserie and Lihoreau 2006), and were a prominent part of the herbivore fauna in the Late Miocene (e.g., Archaeopotamus and Hexaprotodon). Isotope and microwear studies have shown that the Late Miocene hippos already had a tendency for grazing on C4 grasses, in contrast with their browsing anthracotheriid ancestors, although hippos are actually opportunistic feeders rather than obligate grazers and they have retained a variable component of $\mathrm{C} 3$ plants in their diet until recent times (Boisserie et al. 2005; Harris et al. 2008). 


\subsubsection{South America}

After the initial spread of grasslands and the dominance of grazing notoungulates and sloths in the Late Oligocene of Bolivia, the palaeoenvironments of South America were again predominantly forested over most of the continent during the Miocene, until the Late Miocene (ca. $7 \mathrm{Ma}$ ) when they became increasingly dominated by $\mathrm{C} 4$ grasslands (Strömberg 2011). The late Miocene spread of grasslands reflects the global climatic cooling, drying and increased seasonality, but was also affected by the uplift of the Andes (Gregory-Wodzicki 2000; Zachos et al. 2001). This is reflected in the herbivorous mammal communities as a shift from predominantly $\mathrm{C} 3$ browsing to predominantly $\mathrm{C} 4$ grazing during the Late Miocene, similarly to other continents (MacFadden et al. 1996; MacFadden 2000). At this time, South American large herbivorous mammal faunas comprised endemic notoungulates, litopterns and xenarthrans, whereas North American immigrants such as equids, camelids and proboscideans, that became prominent especially in Pleistocene South American faunas, had not yet arrived. Interestingly, most of the notoungulates were already hypsodont in the Early Miocene despite their browse-based diets (e.g., Townsend and Croft 2008), and in fact became largely hypselodont during the Late Miocene (OrtizJaureguizar and Cladera 2006). It has been suggested that this could be explained by the high accumulation of abrasive volcanic ash, which would have created a selection pressure for higher tooth crowns (Strömberg et al. 2013). Among the Xenarthra, the herbivorous sloths and armadillo-related glyptodonts also had hypselodont dentitions, but that is easy to understand as compensation for the lack of enamel in their teeth (Vizcaíno 2009). Microwear analyses of the notoungulates Nesodon, Adinotherium and Protypotherium from the Early Miocene mammal assemblage of Santa Cruz, Argentina, indicate browse-based diets (Townsend and Croft 2008). New mesowear-based dietary analysis indicates browse-based diets also for the sloths (Eucholoeops and Planops) of the Santa Cruz Formation, and a browse-dominated diet for the early glyptodont Propalaeohoplophorus (Saarinen and Karme 2017).

\subsubsection{Australia}

Our knowledge of the Miocene herbivorous marsupial communities of Australia comes from the Miocene records from Riversleigh, Queensland, and Lake Eyre Basin, South Australia. The Early and Middle Miocene palaeoenvironments have been interpreted as rainforests, but during the Late Miocene more open sclerophyllous forests with grassy undergrowth started to be the dominant environments (Travouillon et al. 2009; Strömberg 2011). The browsing diprotodontid Neohelos persisted during the Miocene, and new diprotodontids such as Nimbadon emerged, as well as the bilophodont palorchestids (Propalorchestes) (Archer et al. 1989; Travouillon et al. 2009). Based on craniodental analyses, most of the Miocene kangaroos of Australia were omnivores or browser, and their calcaneal morphology suggests some adaptations to hopping locomotion, although not to the level of 
modern kangaroos (Janis et al. 2016). However, some kangaroos show an increase in hypsodonty from Middle Miocene onwards and there was a hypselodont species of wombatid in the Late Miocene of Riversleigh, suggesting some adaptation to more abrasive or fibrous diets (Dawson and Dawson 2006). A Middle Miocene species of koala, Stealokoala riversleighensis, shows adaptations in dental morphology which indicate the beginning of the specialisation to feeding on fibrous Eucalyptus browse, which culminated in the modern koala (Phascolarctos) (Black 2016).

\subsubsection{Pliocene (5-2.6 Ma): Towards the Ice Age}

After the drastic climatic cooling and drying of the Late Miocene, the Early Pliocene saw a temporary rise in global temperatures, but during latter part of the Pliocene the temperatures dropped again (Herbert et al. 2016). This gradually led to the onset of the Pleistocene ice ages with cyclic short-term variation between cold glacial stages and warmer interglacials (Zachos et al. 2001, 2008). Atmospheric $\mathrm{CO}_{2}$ levels declined during the Late Pliocene (Bartoli et al. 2011). Palaeoenvironmental studies indicate a continuum of increasingly open, C4 grass-dominated savanna- and grassland-environments in tropical and mid-latitude regions such as in Eastern Africa and North America, whereas other regions such as Europe and Southeast Asia were dominated by forests and woodlands. Many genera of grazing-adapted mammals originated during the Pliocene, including the monodactyl horses of the genus Equus, the Asian elephant lineage (Elephas) and the woolly rhinoceroses (Coelodonta).

\subsubsection{Eurasia}

During the Pliocene, relatively warm, forested conditions still prevailed in Europe, with such thermophilous trees as redwood (Sequoia), bald cypress (Taxodium) and hemlocks (Tsuga) growing as far north as in the Great Britain (Head 1998; KovarEder et al. 2008; Strömberg 2011). These conditions were reflected by the presence of such "archaic" browsing forest ungulates as tapirs (Tapirus arvernensis), and the dominance of deer (Cervidae) such as Arvernoceros and Croitzetoceros in the ungulate faunas. The deer were mostly browsers, although there were subtle differences in their diets, e.g., in the locality of Saint-Vallier, France, Croitzetoceros had a more variable, possibly seasonally changing diet than Metacervoceros, as indicated by differences in microwear (Valli and Palombo 2008). They were accompanied by large bovine bovids (Parabos, Alephis), pigs (e.g., Sus strotzzii), brachydont rhinoceroses (Stephanorhinus) and the last hipparionine horses (Plesiohipparion). Rivals and Lister (2016) studied the diets of the Late Pliocene ungulates from Red Crag Nodule Bed, Great Britain, using mesowear and microwear analyses. Their results show that the tapir (Tapirus sp.) and the rhinoceros (Stephanorhinus etruscus) were browsers, the tapir also including some fruit in its diet. The hipparionine horse 
("Hipparion" sp.) from the Red Crag Nodule Bed had a mostly grass-dominated but very flexible diet, ranging from browsing to grazing (Rivals and Lister 2016). The bovid Parabos was a browse-dominated mixed-feeder, and the cervids (cf. Cervus pardinensis and cf. Cervus perrieri) had mixed-feeding and browse-dominated diets, respectively, in the Red Crag Nodule Bed paleoenvironment (Rivals and Lister 2016). The probocideans were represented in Europe by the European mastodon (Mammut borsoni), a very large browsing species, and a browse-dominated mixedfeeding gomphothere Anancus arvernensis (Rivals et al. 2015; Saarinen and Lister 2016). True elephants dispersed to Eurasia from Africa during the Pliocene and became an ecologically important element. Early mammoths migrated from Northern Africa to Europe through an Eastern Mediterranean route. The earliest species of mammoth in Europe, Mammuthus rumanus, had a predominantly browse-based diet, as indicated by microwear analysis of their molar teeth (Rivals et al. 2015).

In Eastern and Southern Asia, the dominant proboscideans were the stegodonts (Stegodon), a group of roughly elephant-like forms with brachydont, multi-lophed cheek teeth. Unlike true elephants, stegodonts retained predominantly browsing diets throughout their evolutionary history and were associated with forest and woodland habitats (Sanders et al. 2010; Zhang et al. 2017). The Upper Siwaliks faunas from Indian subcontinent show diverse large mammal assemblages with bovids (e.g., the early bovine Hemibos), hippopotami (Hexaprotodon), the last surviving anthracotheres (Merycopotamus), giant sivatherine giraffes (Sivatherium), stegodont proboscideans (Stegodon) and early relatives of modern Asian elephant (Elephas planifrons). The diets of these large herbivores ranged from grassdominated (Hipparion, Hemibos, Hexaprotodon and Sivatherium) to mixed-feeding (Merycopotamus) and browsing (Stegodon), based on stable carbon isotope and microwear analyses (Patnaik 2015). Central Asia was dominated by open steppe environments, and the peculiar hypselodont elasmotheriine rhinos of the genus Elasmotherium originated there, probably adapting to very abrasive "hypergrazing" grass-based diets (Zhegallo et al. 2005). The Tibetan plateau served as a place of origin for many genera of cold-adapted ungulates with adaptations to grazing in cold steppe environments, such as the early woolly rhinoceros (Coelodonta thibetana) (Deng et al. 2011). The Pliocene ugulate fauna of the Tibetan plateau, including early mountain-sheeps/goats, hipparionine horses and deer, were feeding on similar C3 photosynthesizing plants as the modern ungulates in that area, as shown by stable isotope analyses (Wang et al. 2013, 2016). Moreover, the isotopes indicate similar high-altitudes but milder temperature than at present (Wang et al. 2013).

\subsubsection{North America}

As a continuum of the drastic environmental changes that started during the Late Miocene, C4 grass -dominated grasslands were abundant environments over much of the continent (Strömberg and McInerney 2011). The earliest Pliocene in North America was largely a continuum of the Late Miocene (Hemphillian) in term of palaeoenvironments and mammal faunas, but very soon during the next stage of the 
Pliocene (Blancan) major changes started to occur (Janis et al. 1998; Morgan and Lucas 2003). One of the most influential events was the formation of a land connection between North and South America, allowing mammals to migrate between the continents (an event known as "the Great American Biotic Interchange") (Woodburne 2010). Although the effect of this faunal interchange was more lasting in South America, it also influenced North America especially through the arrival of megalonychid and mylodontid ground sloths (Megalonyx, Glossotherium) and the large, herbivorous armadillo-related glyptodonts (Glyptotherium).

Horses at this time were represented by the last and small hipparionines (Nannippus) and the modern monodactyl genus Equus, and based on mesowear analyses they were all grazers, in contrast to the Late Miocene hipparionines which included a wider spectrum of grass-dominated mixed-feeders and grazers (Mihlbachler et al. 2011). The artiodactyls were represented by increasingly modern kinds of relatives of camels, including camelines (Camelops) and lamines (Hemiauchenia), antilocaprids (Capromeryx) and browsing deer (Odocoileus, which had migrated to North America from Eurasia) (Morgan and Lucas 2003). The camels, especially Hemiauchenia, had browse-dominated mixed-feeding diets (Feranec 2003), and the antilocaprids of this time hade more grass-dominated diets than later during the Pleistocene and Holocene (Semprebon and Rivals 2007). Rhinoceroses went extinct in North America during the Pliocene but the browsing tapirs (Tapirus) persisted until the end of Pleistocene in wooded and warm environments. The Gray Fossil site in Tennessee, representing a rare record of a subtropical swamp forest environment with browsing tapirs, Teleoceras-rhinos, mastodons and other forest taxa, is now considered to be Early Pliocene rather than Late Miocene in age (Samuels et al. 2018). The Pliocene North American proboscideans included new taxa of derived gomphotheres (Rhynchotherium, Stegomastodon and Cuvieronius) and mammutids (Mammut sp.). Of these, based on tooth morphology and tooth wear, Mammut sp. was a browser and the gomphotheres more opportunistic mixed-feeders (Rivals et al. 2012; Sánchez et al. 2004).

\subsubsection{Africa}

The Pliocene was a time when the open, C4-grass dominated grassland savannas started to emerge in East Africa after the initial spread of grassy woodland savannas during the Late Miocene (Cerling et al. 1997; Strömberg 2011). However, woodland savannas and associated browser and mixed-feeder dominated herbivorous mammal faunas still prevailed, as indicated by sites such as the Upper Laetoli beds in Tanzania (Bamford 2011a, b; Kaiser 2011). Based on stable carbon isotope studies, the large herbivore faunas of the Turkana Basin in East Africa were dominated by mixed-feeders during the Pliocene, becoming dominated by specialised C4-grass grazers much later, at about the beginning of the Pleistocene ca. 2.5 Ma (Cerling et al. 2015). This also concurs with other palaeoecological and palaeoenvironmental studies, which suggest that the savanna-like environments of the Pliocene were still 
largely more wooded than in the Pleistocene in East Africa (e.g., Bamford 2011a, b; Fortelius et al. 2016).

The fossil mammal faunas were rich, dominated by Bovidae representing all the modern tribes of African bovids (Tragelaphini, Alcelaphini, Antilopini, Hippotragini, Reduncini and Cephalophini), and pigs (Suidae) represented by such abundant taxa as Notochoerus and Kolpochoerus. Based on tooth wear and stable isotope studies, both the bovids and the suids included $\mathrm{C} 4$ grazers as well as mixedfeeders and browsers (e.g., Uno et al. 2011; Kaiser 2011). Perissodactyls were less diverse and abundant but were still common elements of the mammal faunas, including grazing hipparionine horses (Eurygnathohippus), both browsing and grazing rhinoceroses (Diceros and Ceratotherium, respectively) and rare late-surviving chalicotheres, which would probably have been browsers feeding on leaves and bark of trees and shrubs (Ancylotherium) (Uno et al. 2011; Kaiser 2011; see also Semprebon et al. 2011). The proboscideans were diverse and abundant, and they were represented by several often sympatric species including the browsing deinothere Deinotherium bozasi, the grazing or mixed-feeding gomphothere Anancus and predominantly grazing elephants representing the lineages of modern African and Asian elephants (Loxodonta adaurora, L. exoptata and Elephas recki) (Cerling et al. 1999; Uno et al. 2011; Saarinen et al. 2015).

\subsubsection{South America}

A shift from mostly C3 browsing to predominantly C4 grass-based diets occurred during the Late Miocene in many endemic South American ungulates, but other isotopic evidence suggests that some Pliocene toxodont notoungulates from the Andes retained C3-plant based diets, possibly due to high altitude (MacFadden et al. 1994). Otherwise, detailed palaeodietary analyses seem to be largely lacking for the Pliocene of South America, although Ortiz-Jaureguizar and Cladera (2006) indicate that South American Pliocene faunas were dominated by "grazing types". However, the dietary spectrum of Pliocene South American herbivores was probably much wider, e.g., the common small, burrowing notoungulate Paedotherium typicum from the savanna-like paleoenvironment of Chapadmalal, Argentina, was probably a mixed-feeder of low-growing vegetation in various habitats (Croft 2016). Moreover, a peccary (Platygonus marplatensis) from Chapadmalal had incipiently bilophodont molars and probably largely browsing/frugivorous diet (Croft 2016). During the Late Pliocene the opening of the land connection between North and South America allowed some new groups of large herbivorous mammals to migrate from North to South America, including some peccaries and camels, but the main event of the Great American interchange and the subsequent faunal changes coincides with the beginning of the Pleistocene ca. 2.6 Ma (MacFadden et al. 1994; Woodburne 2010). 


\subsubsection{Australia}

Analysis of the Chinchilla fossil mammal community indicates that the Pliocene palaeoenvironments of Queensland in Australia were mosaic-like with tropical forests, wetlands and grasslands (Montanari et al. 2013). Based on stable isotopes, the kangaroo Macropus sp. was a mixed-feeder on both $\mathrm{C} 3$ and $\mathrm{C} 4$ plants, and the kangaroos Troposodon and Protemnodon, as well as the large diprotodontid Euryzygoma were browse-dominated mixed-feeders with a preference for C3 plants (Montanari et al. 2013). Mesowear analysis of several species of Plio-Pleistocene kangaroos from Australia indicates that most of these species were mixed-feeders (Butler et al. 2014).

\subsubsection{Pleistocene (2.6 Ma-10 Ka): The Time of the Ice Ages}

The Pleistocene Ice Age started when the global cooling trend had reached a point after which periodical glaciation events started in the Northern hemisphere following cyclic changes in the orbit and axis orientation of the Earth (e.g., Hays et al. 1976; Zachos et al. 2001; Lisiecki and Raymo 2007; Walker and Lowe 2007; Zachos et al. 2008). Continental glaciation of the Antarctic had started much earlier, already in the Oligocene (Zachos et al. 2008). However, at the beginning of the Pleistocene the global cooling intensified the effect of the cyclic changes in the Earth's orbit and axis on climatic changes, causing summer temperatures to drop periodically low enough for the accumulation of large continental ice sheets (glaciers) in northern Europe and in northern North America (Zachos et al. 2008; Lisiecki and Raymo 2007; Walker and Lowe 2007). Since then the climate oscillated between the extremes of cold glacial maxima and warm interglacial stages in Northern hemisphere, and the changes in climate have often been complex and rapid (e.g., Walker and Lowe 2007).

The cold, dry and dramatically oscillating climates of the Pleistocene had a profound effect on all life on earth, shaping vegetation patterns and animal communities, and creating heavy selection and extinction pressures on organisms (e.g., Kurtén 1968, 1972; Kurtén and Anderson 1980; Geist 1998; Guthrie 2001). The cold climatic conditions of the Pleistocene increased plant productivity and quality due to the fertile soils generated by intense glacial erosion and the reduced chemical defences and fibrousness of plants, providing abundant resources for large herbivores, resulting in the evolution of particularly large species with impressive luxury organs (horns, antlers and tusks) (e.g., Zimov et al. 1995; Geist 1998; Saarinen et al. 2014). Atmospheric $\mathrm{CO}_{2}$ content oscillated following the glacial-interglacial cyclicity, which could also have had an impact on the extent of grassland (especially C4 grass) environments (e.g., Archer et al. 2000). Pleistocene herbivorous mammal communities, across the world, are typically characterized by dietary successions from browsers to grazers, with grazers dominating open grassland environments and 
browsers dominating forest environments. Mixed-feeders were typical in both kinds of palaeoenvironments. The Pleistocene ended with the mass extinction of megafauna, which led to the impoverished herbivore communities of the Holocene (Barnosky et al. 2004).

\subsubsection{Eurasia}

In Eurasia the cyclic changes in the Pleistocene climate caused especially dramatic periodical changes in biome distributions and environments. There was a general shift during the Early Pleistocene from forests to open savanna-like environments, especially in Southern Europe but also as far north as in England, where semi-open, boreal grassland-heathland environments prevailed during the cool glacial stages and woodland environments during the warm interglacials (e.g., West 1980). Later during the Pleistocene, successions of forest vegetation in Europe and Northern Eurasia were characteristic of the warm interglacial stages (e.g., Stuart 1976). During the glacial stages, especially in the Late Pleistocene, continental ice sheets and mountain ranges blocked moisture from reaching the Eurasian inland areas and caused long-term cold and dry high-pressure climates which resulted in the vast "mammoth steppe" vegetation to spread over the continent (Guthrie 2001). Trampling and grazing by abundant large herbivorous mammals also contributed in maintaining the grass-dominated vegetation of the mammoth steppes (Zimov et al. 1995). South-Eastern Asia remained dominated by tropical and subtropical forests and savannas during the Pleistocene.

In Europe and Northern Eurasia, the constantly changing climatic and environmental conditions of the Early and Middle Pleistocene favoured large herbivorous mammal species which were able to adapt to these changes and tended to have rather opportunistic dietary strategies, being able to change their diets based on environmental changes despite their adaptations to either grazing or browsing. Many "archaic" mammals which were adapted to the warm forest environments of the Pliocene and had browsing diets, such as tapirs (Tapirus) and the European mastodon (Mammut borsoni) went extinct in Europe at the transition from Pliocene to Pleistocene. Also the last hipparionine horses went extinct and were replaced by the modern horses (Equus), which migrated to Eurasia (and somewhat later to Africa) at the beginning of the Pleistocene. The large herbivorous mammal communities of the Pleistocene typically show a continuum of dietary strategies from browsers to mixed-feeders and grazers. For example in the Early Pleistocene community of Coste San Giacomo from Italy where the deer (Axis, Eucladoceros and Croitzetoceros) were browsers, the bovids (Gallogoral, Gazella and Leptobos) were predominantly mixed-feeders, and the horse (Equus stenonis) was a grazer, as shown by dental mesowear analysis (Strani et al. 2015). However, the flexibility of dietary strategies, which enabled mammals to cope with the variable and changing climatic and environmental conditions, are clearly indicated by dental mesowear and microwear analyses: e.g., the rhinoceros Stephanorhinus hudsheimensis was able to shift its diets from browsing in a forest environment to mixed-feeding in an open 
environment (Kahlke and Kaiser 2011; Van Asperen and Kahlke 2015). Similarly, the gomphotheriid proboscidean Anancus arvernensis and the ancestral mammoth Mammuthus meridionalis were able to shift their diets according to environmental conditions, despite A. arvernensis being more adapted to browsing and M. meridionalis to grazing (Rivals et al. 2015; Saarinen and Lister 2016).

During the latter part of the Pleistocene, the glacial-interglacial cyclicity intensified, and the warm forest-adapted interglacial faunas (the so-called PalaeoloxodonStephanorhinus - chronofaunas) alternated with the cold steppe-adapted Mammuthus-Coelodonta (woolly mammoth-woolly rhino) chronofaunas locally over much of the Northern Eurasia (Kahlke 1999; Pushkina 2007). Also these Middle and Late Pleistocene mammal communities demonstrate a dietary spectrum from browsers (moose (Alces alces), roe deer (Capreolus capreolus) and Merck's rhinoceros (Stephanorhinus kirchbergensis)) to mixed-feeders (giant deer (Megaloceros giganteus), red deer (Cervus elaphus), fallow deer (Dama dama), reindeer (Rangifer tarandus) and the narrow-nosed rhinoceros (Stephanorhinus hemitoechus)) to grass-dominated mixed-feeders (steppe bison (Bison priscus), aurochs (Bos primigenius)), to grazers (wild horse (Equus ferus) and woolly rhinoceros (Coelodonta antiquitatis)) (Rivals et al. 2010; Rivals and Lister 2016; Saarinen et al. 2016). However, again dental mesowear and microwear analyses show that there was typically local variation in the diets of these species, following changes in vegetation (Rivals and Lister 2016; Saarinen et al. 2016). The diets of mountainadapted caprine bovids ranged from mixed-feeding (Rupicapra pyrenaica and Capra caucasica in the Late Pleistocene of France) to grazing (Middle Pleistocene argali-like sheep (Ovis ammon antiqua) from Caune de l'Arago, France) in highaltitude meadows, as indicated by dental microwear analyses (Rivals and Deniaux 2003, 2005). The ancestral mammoth (Mammuthus meridionalis) was replaced in the Middle Pleistocene by a more specialised woodland species with browsedominated mixed-feeding diet, the straight-tusked elephant (Palaeoloxodon antiquus), and a more specialised open adapted grazing species, the steppe mammoth (Mammuthus trogontherii) (Saarinen and Lister 2016). Finally, the cold adapted woolly mammoth (Mammuthus primigenius) became the only species of elephant in Europe and Northern Eurasia during the last glaciation. Based on dental microwear and mesowear analyses, all of these species of elephant, even the woolly mammoth with the strongest adaptation to grazing (the most hypsodont molars with the highest number of enamel ridges), had quite large variation in their diets following again changes in environments and vegetation structure (Rivals and Lister 2016; Saarinen and Lister 2016).

\subsubsection{North America}

In North America, a roughly similar pattern occurred as in Northern Eurasia, except that throughout the Pleistocene the environmental differences were not as great between glacial and interglacial stages but were greater between the heavily forested eastern part of the continent and the dry, grassland-dominated western part 
(Williams et al. 1998). However, a much larger area of North America was covered by ice sheets during the glacial stages than in Eurasia, and north of the ice sheet the mammal fauna was similar to the Siberian mammoth steppes, whereas south of the ice there were forests and grassland habitats throughout the Pleistocene (Williams et al. 1998; Guthrie 2001).

The diets of Pleistocene North American large herbivores were characteristically diverse, ranging from browsers (e.g., moose (Alces alces), white-tailed deer and mule deer (Odocoileus), American mastodon (Mammut americanum) and Jefferson's ground sloth (Megalonyx jeffersoni)) to abundant, often grass-dominated mixed-feeders (e.g., antilocaprids, bisons (Bison) and the Columbian mammoth (Mammuthus columbi) and obligate grazers (e.g., horses (Equus) and Harlan's ground sloth (Paramylodon harlani)) (Rivals et al. 2007; Semprebon and Rivals 2007; Mihlbachler et al. 2011; Rivals et al. 2012; Saarinen et al. 2015; Saarinen and Karme 2017). Dental mesowear and microwear analyses indicate that the diets of the Pleistocene North America bisons (Bison sp.) were less heavily abrasive than in the modern plains bison (Bison bison), which is a "hyper-grazer" among bovids (Rivals et al. 2007). The camels in North America during the Pleistocene, including Camelops, Hemiauchenia and Palaeolama were all browse-dominated feeders, based on dental mesowear and microwear analyses (Semprebon and Rivals 2010). The Pleistocene antilocaprids (Tetrameryx, Stockoceros, Capromeryx and Antilocapra) had less abrasive mesowear signals and more C3 dominated diets than their Pliocene predecessors, but their microwear analyses still suggest grazing, indicating perhaps specialisation to utilising relatively non-abrasive C3 photosynthesising grasses (Semprebon and Rivals 2007). The mesowear based analysis of North American horses through time (Mihlbachler et al. 2011) indicates that the Equus-horses in the Pleistocene of North America were all grazers. Microwear analysis indicates that the flat-headed peccary (Platygonus compressus) had predominantly omnivorous/browsing diet (Schmidt 2008). Within the proboscideans, the American mastodon (Mammut americanum) with brachydont, lophodont molars was a dedicated browser and is typically associated with forest environments, whereas the Columbian mammoth (Mammuthus columbi) occupied more open habitats, had specialised hypsodont dentition and was clearly adapted to grazing, but had quite variable diet ranging from browse-dominated to grazing (Rivals et al. 2012; Saarinen et al. 2015). Dental mesowear and microwear analyses of the Late Pleistocene ungulate community of Alaska indicate unusually heavily grass-dominated dietary spectrum, with even typically browsing or mixed-feeding deer such as Rangifer and Cervus being grazers despite their brachydont teeth (Rivals et al. 2010).

\subsubsection{Africa}

The palaeoenvironments of East Africa became increasingly dominated by open C4 grasslands during the Pleistocene (e.g., Cerling et al. 1997; Jacobs et al. 2010). The ungulate communities were by now clearly dominated by abundant and diverse 
bovids. Based on stable isotope studies, the Pleistocene large herbivorous mammal faunas became dominated by $\mathrm{C} 4$ grazers, including alcelaphine (e.g., Megalotragus, Connochaetes, Alcelaphus), bovine (e.g., Pelorovis) and reduncine (e.g., Kobus) bovids, zebras (Equus), suids of the Metridiochoerus-Phacochoerus lineage, the white rhinoceros (Ceratotherium), elephants (Elephas and Loxodonta) and even sivatherine giraffes (Sivatherium) (Cerling et al. 2015). Also hippos (Hippopotamus) were locally $\mathrm{C} 4$ grazers in some regions such as Turkana and Nakuru. The less diverse browsers included the black rhinoceros (Diceros), giraffe (Giraffa), cephalophine bovids and the last surviving deinotheriid proboscidean Deinotherium bozasi (Cerling et al. 2015). Some lineages of large herbivores, such as the African elephant (Loxodonta africana) and suids of the Kolpochoerus-Hylochoerus lineage, shifted their diet from $\mathrm{C} 4$-grass dominated grazing to $\mathrm{C} 3$-dominated browsing from the Pleistocene to the Holocene (Cerling et al. 2015). Also, dental mesowear analysis of the Middle Pleistocene to Holocene bovids from the Kibish Formation, Ethiopia, shows that all of the taxa shifted their diets to less abrasive (more browse-dominated) from the Pleistocene to the Holocene (Rowan et al. 2015).

\subsubsection{South America}

During the Early Pleistocene, the Great American Biotic Interchange between North and South America resulted in the introduction of many new groups of large herbivorous mammals from North to South America, such as gomphotheriid proboscideans (Stegomastodon, Cuvieronius), lamine camels (e.g., Palaeolama), horses (Onohippidion, Hippidion, Equus), deer (which radiated into many endemic South American genera such as Ozotoceros, Hippocamelus and Mazama) and tapirs (Tapirus) (Woodburne 2010). Of these, proboscideans and horses went extinct in South America at the end of the Pleistocene. The new immigrants formed diverse mammal communities together with the endemic South American mammals, such as notoungulates (e.g., Toxodon), litopterns (e.g., Macrauchenia) and xenarthans, including diverse megatheriid, megalonychid and mylodontid ground sloths (e.g., Megatherium, Nothrotherium, Glossotherium, Lestodon and Scelidotherium) and herbivorous armadillo-related glyptodonts (e.g., Glyptodon, Neosclerocalyptus, Doedicurus) and pampatheres (e.g., Holmesina).

MacFadden et al. (1994) analysed the dietary composition of the typical Pleistocene South American ungulates. Their results indicate a continuum of diets from browsing to grazing, similar to the other continents during the Pleistocene: among the horses, Hippidion had C3-plant dominated (browsing) diets, Onohippidion had mixed $\mathrm{C} 3 / \mathrm{C} 4$ diets and Equus had C4 grass -dominated diets, and similarly among the lamine camels, Palaeolama had C3-dominated and Lama C4 grass -dominated diets. The gomphothere Cuvieronius had highly variable isotope signals indicating a diet based on wide range of plants. Finally, based on the isotope analyses, the large, hypselodont notoungulate Toxodon was a $\mathrm{C} 4$ grazer, whereas the litoptern Macrauchenia was a browser on C3 photosynthesising vegetation. New stable isotope analyses of South American Pleistocene gomphotheres indicate that most 
of them were mixed-feeders, but their diets varied considerably according to environmental conditions (Sánchez et al. 2004). For example, the population of Cuvieronius from Chile had exclusive $\mathrm{C} 3$ diets whereas the populations from Bolivia and Ecuador had mixed C3/C4 diets. The diets of Stegomastodon varied even more, ranging from $\mathrm{C} 3$ browsing in Argentina to $\mathrm{C} 4$ grazing in Ecuador. This kind of flexibility in diet is typical for Pleistocene herbivorous mammals on other continents too, and is particularly pronounced in proboscideans (Rivals et al. 2012, 2015, Rivals and Lister 2016; Saarinen et al. 2016; Saarinen and Lister 2016).

Finally large herbivorous xenarthrans, including several species of giant ground sloths, glyptodonts and pampatheres, were abundant, adding to the already diverse large herbivore faunas (Fariña 1996; Vizcaíno 2009). In fact, it has been puzzling how such abundant and diverse megaherbivore communities could have coexisted in the Pleistocene South American palaeoenvironments (see Fariña 1996). However, Saarinen and Karme (2017) noted, based on new dental mesowear analysis, that there were significant differences between the diets of the Pleistocene xenarthrans: among the ground sloths Megatherium and Nothrotherium were specialised browsers, whereas the various mylodontid sloths had diets ranging from mixedfeeding (Glossotherium) to grazing (Scelidotherium and Lestodon). Among the glyptodonts, Neosclerocalyptus and Glyptodon were grass-dominated mixedfeeders, whereas the pampatheres, such as Holmesina, were most likely specialised grazers. These new dietary observations are in agreement with previous results based on ecomorphological, stable isotope and microwear analyses (e.g., Bargo et al. 2006; Vizcaíno 2009; Domingo et al. 2012; Green and Resar 2012), but revealed more diversity in the diets than had been anticipated.

\subsubsection{Australia}

The Pleistocene herbivorous marsupial faunas of Australia were diverse and included species with highly varied diets, paralleling the patterns seen on other continents. Based on stable isotope and dental microwear analyses, DeSantis et al. (2017) were able to resolve the diets of the Middle Pleistocene megafauna from Cuddie Springs, and found them to be largely browse-dominated. Among kangaroos, the "shortfaced" kangaroo Sthenurus was a browser in more dense-canopy environments than the rest of the taxa, Protemnodon appears to have been a browser consuming C3 browse but also C4 photosynthesising shrubs, and Macropus a mixed-feeder feeding more heavily on $\mathrm{C} 4$ grasses and shrubs. Stable isotope and dental microwear analyses indicate that the giant Pleistocene short-faced kangaroo, Procoptodon goliath, was a specialised browser of chenopods and $\mathrm{C} 4$ photosynthesising saltbushes (Prideaux et al. 2009). All the Pleistocene kangaroos seem to have been more browsedominated feeders than the modern grazing kangaroos. The diprotodontids, including the giant, megaherbivore-sized Diprotodon and the somewhat smaller Zygomaturus, were browsers or mixed-feeders with seasonally varying diets. The wombats Phascolonus and Vombatus were the most heavily C4-dominated grazers, as wombats are today (DeSantis et al. 2017). There was a considerable drying and 
desertification of environments from the Middle to Late Pleistocene in Australia, which led to a restriction in the diets of the herbivorous marsupials from $\mathrm{C} 4$ plants to increasingly C3-dominated vegetation (DeSantis et al. 2017).

\subsection{Discussion}

The evolutionary history of browsing and grazing and be summarized as follows:

- Many lineages of frugivorous-folivorous mammals evolved from omnivorous ancestors during the Palaeocene and early Eocene, including early artiodactyls, perissodactyls and proboscideans.

- Specialised folivorous browsing mammals evolved and prevailed during the Eocene and the Oligocene, and continued to be the dominant elements in most parts of the world until the Late Miocene.

- Following the spread of grassland environments, the major shift from browsing to grazing happened in many major lineages of large herbivorous mammals (e.g., bovids and elephants) during the Late Miocene. However, following the earlier emergence of grassland environments, the earliest grazers evolved during the Oligocene in South America among notoungulates and sloths, and in North America during the mid-Miocene among equine horses. Morphological adaptations to grazing in herbivorous mammals follows the emergence of new (abundant) resources, first the increase in $\mathrm{C} 3$ grasses, and then that of $\mathrm{C} 4$ grasses. This emergence of resources is a reaction to changing rainfall patterns, temperature and $\mathrm{CO}_{2}$-levels, all of which react to tectonic movements and tilt of the earth's axis.

- During the Pliocene and Pleistocene, and to a lesser degree in Holocene and modern times, diverse herbivore faunas with a dietary spectrum ranging from browsers to grazers have been typical in all continents. The dietary spectrum of the species, and dietary variation within species, reflect environmental and climatic variations locally and through time.

I have deliberately concentrated in discussing the dietary history of specialised large terrestrial herbivorous mammals such as ungulates, proboscideans and herbivorous xenarthrans and marsupials, and left out primates (which have specialised, often arboreal lifestyles) and small mammals (especially rodents, which are predominantly herbivorous but are able to utilise micro-niches in their environments). However, primates and rodents do, in fact, show roughly similar dietary histories as well, starting out as omnivores and frugivores, and later specialising at browsing and in some cases grazing. For example, many cercopithecid monkeys, which were the dominant primates in African forests from the Miocene until today, were specialised leaf browsers, whereas giant baboons (Theropithecus oswaldi) occupying East African savannas in the Plio-Pleistocene were grazers (Cerling et al. 2013). In fact, even some early human relatives (Paranthropus boisei) could have been feeding on C4 grasses (or their seeds) in East Africa during the Early Pleistocene (Cerling et al. 2011). 
The various proxy methods (stable isotope analyses and dental microwear and mesowear) together provide us with an increasingly comprehensive set of tools for examining the diets of fossil herbivorous mammals, especially browsing vs. grazing. Whereas the ecomorphology of fossil mammals such as tooth crown height and complexity of their enamel patterns give valuable clues to what they were adapted to eat, the tooth wear and isotope proxies enable us to see variation in their diets at the level of ancient populations and even individuals. Thus we are now provided with fascinatingly detailed information about past herbivores' diets. For example, recent studies of dental mesowear have revealed a roughly similar evolution of dietary strategies in many groups throughout their evolutionary history, for example the horses (Equidae): they started as relatively generalistic herbivores feeding on leaves, fruit and seeds in tropical and subtropical forests, shifted to browsing in increasingly seasonal forests and woodlands, and finally shifted towards increasingly grass-based diets when grassland environments started to spread (Mihlbachler et al. 2011). Despite adaptations to utilising different diets, many large herbivorous mammals kept a degree of flexibility in their diet, being able to shift it according to changing environmental conditions (e.g., Rivals and Lister 2016; Saarinen et al. 2016; Saarinen and Lister 2016).

Acknowledgements I thank Jenny and Antti Wihuri Foundation for funding my work as a post doc researcher in the Natural History Museum of London during this work. I would also like to thank Christine Janis and Iain Gordon for their constructive suggestions which helped me improve this chapter.

\section{Glossary}

Cenozoic the last ca. 66 million years that started from the end-Cretaceous mass extinction and continues today. The Cenozoic is characterized by a warm and humid beginning followed by mostly cooling and drying global climate, which led to the spread of open, arid environments and grasslands. It is also the time when mammals diversified and filled the ecological niches of large terrestrial herbivores.

Neogene ca. 23-2.6 million years ago, during which climatic cooling and drying led to increasing coverage of grass-dominated open habitats in many parts of the world, driving the evolution of adaptations to grazing in many lineages of herbivorous mammals.

Pleistocene ca. 2.6 million years to ca. 11,000 years ago, until the present warmclimatic stage. This was the time of the ice ages characterized by strong cyclic variations in climate, environments and the distribution of plants and animals in the northern hemisphere.

Mesowear dietary analysis method applicable to present and fossil mammals, based on the wear-induced shape of the occlusal surface of molar teeth. It indicates the amount of grass (in relation to browse) in diet. 
Microwear dietary analysis method based on microscopic wear marks on tooth enamel, which reflect the relative amounts of grass, browse, seeds and other dietary items during the last days of an animal's life.

Bunodont tooth morphology type where the cusps are separate and not fused or connected by elongated ridges.

Lophodont tooth morphology type where the cusps are elongated and connected into long cutting ridges (lophs).

Plagiolophodont derived lophodont tooth morphology where the lophs are folded and fused to form a flat occlusal surface with shearing enamel edges, often supported by extensive dental cement that covers the tooth crown.

Selenodont tooth morphology type where the cusps have been elongated into crescent-shaped cutting blades. This is the typical tooth morphology of ruminants and camels.

Bilophodont tooth morphology type where anterior and posterior cusp pairs have been fused into two transverse cutting lophs.

Loxodont tooth morphology type where the amount of transverse cutting lophs has been multiplied to form an efficient shearing surface with multiple enamel ridges, often supported by extensive dental cement between the lamellae.

Hypsodont a relatively high tooth crown, as opposed to Brachydont which refers to a relatively short crown.

Perissodactyla odd-toed ungulates, including horses (Equidae), rhinoceroses (Rhinocerotidae), tapirs (Tapiridae) and many extinct families such as chalicotheres (Chalicotheriidae), brontotheres (Brontotheriidae), paleotheres (Palaeotheriidae), hyracodonts (Hyracodontidae) and amynodonts (Amynodontidae).

Artiodactyla even-toed ungulates, including ruminants (Ruminantia), camels (Camelidae), pigs (Suidae), peccaries (Tayassuidae), hippopotami (Hippopotamidae) and many extinct families such as anthracotheres (Anthracotheriidae), entelodont (Entelodontidae) and oreodonts (Merycoidodontidae).

Proboscidea the mammal order that comprises elephants and their fossil relatives

Xenarthra the mammal order containing sloths, armadillos, anteaters and their fossil relatives such as glyptodonts and ground sloths.

Notoungulata an extinct order of endemic South American ungulates.

Litopterna an extinct order of endemic South American ungulates.

\section{References}

Agustí J, Moya-Sola S (1990) Mammal extinctions in the Vallesian (Upper Miocene). In: Kauffman EG (ed) Extinction events in earth history, vol IV. Springer, Berlin, pp 425-432

Alroy J (1998) Cope's rule and the dynamics of body mass evolution in North American fossil mammals. Science 280:731-734

Archer M, Godthelp H, Hand SJ, Megirian D (1989) Fossil mammals of Riversleigh, Northwestern Queensland: preliminary overview of biostratigraphy, correlation and environmental change. Aust Zool 25:29-65 
Archer D, Winguth A, Lea D, Mahowald N (2000) What caused the glacial/interglacial atmospheric $p \mathrm{CO}_{2}$ cycles? Rev Geophys 38:159-189

Bamford MK (2011a) Fossil woods. In: Harrison T (ed) Paleontology and geology of Laetoli: human evolution in context: volume 1: geology, geochronology, paleoecology and paleoenvironment. Springer, Amsterdam, pp 217-134

Bamford MK (2011b) Fossil leaves, fruits and seeds. In: Harrison T (ed) Paleontology and geology of Laetoli: human evolution in context: volume 1: geology, geochronology, paleoecology and paleoenvironment. Springer, Amsterdam, pp 235-252

Bargo MS, Toledo N, Vizcaíno SF (2006) Muzzle of South American Pleistocene ground sloths (Xenarthra, Tardigrada). J Morphol 267:248-263

Barnosky AD, Koch PL, Feranec RS, Wing SL, Shabel AB (2004) Assessing the causes of Late Pleistocene extinctions on the continents. Science 306:70-75

Bartoli G, Hönisch B, Zeebe RE (2011) Atmospheric CO2 decline during the Pliocene intensification of Northern Hemisphere glaciations. Paleoceanography 26:PA4213. https://doi.org/10. 1029/2010PA002055

Beard C (1998) East of Eden: Asia as an important center of taxonomic origination in mammalian evolution. Bull Carnegie Mus Nat Hist 34:5-39

Bernor RL, Semprebon G, Damuth J (2014) Maragheh ungulate mesowear: interpreting paleodiet and paleoecology from a diverse fauna with restricted sample. Ann Zool Fenn 51:201-208

Bibi F (2007) Dietary niche partitioning among fossil bovids in late Miocene C3 habitats: consilience of functional morphology and stable isotope analysis. Palaeogeogr Palaeoclimatol Palaeoecol 253:529-538

Black KH (2016) Middle Miocene origins for tough-browse dietary specialisations in the koala (Marsupialia, Phascolarctidae) evolutionary tree: description of a new genus and species from the Riversleigh World Heritage Area. Mem Mus Vic 74:255-262

Blondel C (1998) Etude morphologique du squelette appendiculaire des ruminants de l'OligoceÁne d'Europe occidentale; implications environnementales. C R Acad Sci 326:527-532

Blondel C (2001) The Eocene-Oligocene ungulates from Western Europe and their environment. Palaeogeogr Palaeoclimatol Palaeoecol 168:125-139

Boardman GS, Secord R (2013) Stable isotope paleoecology of White River ungulates during the Eocene-Oligocene climate transition in northwestern Nebraska. Palaeogeogr Palaeoclimatol Palaeoecol 375:38-49

Boisserie J-R, Lihoreau F (2006) Emergence of Hippopotamidae: new scenarios. C R Palevol 5:749-756

Boisserie J-R, Zazzo A, Merceron G, Blondel C, Vignaud P, Likius A, Mackaye HT, Brunet M (2005) Diets of modern and late Miocene hippopotamids: evidence from carbon isotope composition and micro-wear of tooth enamel. Palaeogeogr Palaeoclimatol Palaeoecol 221:153-174

Butler K, Louys J, Travouillon K (2014) Extending dental mesowear analyses to Australian marsupials, with applications to six Plio-Pleistocene kangaroos from Southeast Queensland. Palaeogeogr Palaeoclimatol Palaeoecol 408:11-25

Butler K, Travouillon KJ, Price GJ, Archer M, Hand SJ (2017) Species abundance, richness and body size evolution of kangaroos (Marsupialia: Macropodiformes) throughout the OligoMiocene of Australia. Palaeogeography, Palaeoclimatology, Palaeoecology. https://doi.org/10. 1016/j.palaeo.2017.08.016

Calandra I, Göhlich UB, Merceron G (2008) How could sympatric megaherbivores coexist? Example of niche partitioning within a proboscidean community from the Miocene of Europe. Naturwissenschaften 95:831-838

Cerling TE (1992) Development of grasslands and savannas in East Africa during the Neogene. Palaeogeogr Palaeoclimatol Palaeoecol 97:241-247

Cerling TE, Harris JM, MacFadden BJ, Leakey MG, Quade J et al (1997) Global change through the Miocene/Pliocene boundary. Nature 389:153-158

Cerling TE, Harris JM, Leakey MG (1999) Browsing and grazing in elephants: the isotope record of modern and fossil proboscideans. Oecologia 120:364-374 
Cerling TE, Mbua E, Kirera FM, Manthi FK, Grine FE, Leakey MG, Sponheimer M, Uno KT (2011) Diet of Paranthropus boisei in the early Pleistocene of East Africa. PNAS 108:9337-9341

Cerling TE, Chritz KL, Jablonski NG, Leakey MG, Manthi FK (2013) Diet of Theropithecus from 4 to 1 Ma in Kenya. PNAS 110:10507-10512

Cerling TE, Andanje SA, Blumenthal SA, Brown FH, Chritz KL, Harris JM, Hart JA, Kirera FM, Kaleme P, Leakey LN, Leakey MG, Levin NE, Manthi FK, Passey PK, Uno KT (2015) Dietary changes of large herbivores in the Turkana Basin, Kenya from 4 to 1 Ma. PNAS 112:11467-11472

Clauss M, Rössner GE (2014) Old world ruminant morphophysiology, life history, and fossil record: exploring key innovations of a diversification sequence. Ann Zool Fenn 51:80-94

Collinson ME (1992) Chapter 22: Vegetational and foristic changes around the Eocene/Oligocene boundary in Western and Central Europe. In: Prothero DR, Berggren WA (eds) EoceneOligocene climatic and biotic evolution. Princeton University Press, Oxford, pp 437-450

Collinson ME, Hooker JJ (1987) Vegetational and mammalian faunal changes in the early tertiary of Southern England. In: Chaloner WG, Crane PR, Friis EM (eds) The origin of angiosperms and their biological consequences. Cambridge University Press, Cambridge, pp 259-304

Coombs MC (1978) Additional Schizotherium material from China, and a review of Schizotherium dentitions (Perissodactyla, Chalicotheriidae). Am Mus Novit 2647:1-18

Croft DA (2016) Horned armadillos and rafting monkeys - the fascinating fossil mammals of South America. Indiana University Press, Bloomington, IN

Croft DA, Weinstein D (2008) The first application of mesowear method to endemic South American ungulates (Notoungulata). Palaeogeogr Palaeoclimatol Palaeoecol 269:103-114

Damuth J, Janis CM (2011) On the relationship between hypsodonty and feeding ecology in ungulate mammals, and its utility in palaeoecology. Biol Rev 86:733-758

Damuth J, Janis CM (2014) A comparison of observed molar wear rates in extant herbivorous mammals. Ann Zool Fenn 51:188-200

Dawson TJ, Dawson L (2006) Evolution of arid Australia and consequences for vertebrates. In: Merrick JR, Archer M, Hickey GM, Lee MSY (eds) Evolution and biogeography of Australasian vertebrates. Auscipub, Sydney, pp 51-70

De Franceschi D, Hoorn C, Antoine PO, Cheema IU, Flynn LJ, Lindsay EH, Marivaux L, Metais G, Rajpar R, Welcomme J-L (2008) Floral data from themid-Cenozoicof Central Pakistan. Rev Palaeobot Palynol 150:115-129

DeMiguel D, Fortelius M, Azanza B, Morales J (2008) Ancestral feeding state of ruminants reconsidered: earliest grazing adaptation claims a mixed condition for Cervidae. BMC Evol Biol 8:1-13

Deng T, Wang X, Fortelius M, Li Q, Wang Y, Tseng ZJ, Takeuchi GT, Sylor JE, Säilä LK, Xie G (2011) Out of Tibet: Pliocene woolly rhino suggests high-plateau origin of Ice Age megaherbivores. Science 333:1285-1288

DeSantis LRG, Field JH, Wroe S, Dodson JR (2017) Dietary responses of Sahul (Pleistocene Australia-New Guinea) megafauna to climate and environmental change. Paleobiology 43:181-195

Domingo L, Prado JL, Alberdi MT (2012) The effect of paleoecology and paleobiogeography on stable isotopes of Quaternary mammals from South America. Quat Sci Rev 55:103-113

Erlebe JJ, Greenwood DR (2012) Life at the top of the greenhouse Eocene world - a review of the Eocene flora and vertebrate fauna from Canada's High Arctic. Geol Soc Am Bull 124:3-23

Eronen JT, Puolamaki K, Liu L, Lintulaakso K, Damuth J et al (2010a) Precipitation and large herbivorous mammals II: application to fossil data. Evol Ecol Res 12:235-248

Eronen JT, Evans AR, Fortelius M, Jernvall J (2010b) The impact of regional climate to the evolution of mammals: a case study using fossil horses. Evolution 64:398-408

Eronen JT, Kaakinen A, Liu L-P, Passey BH, Tang H, Zhang Z-Q (2014) Here be dragons: Mesowear and tooth enamel isotopes of the classic Chinese "Hipparion" faunas from Baode, Shanxi Province, China. Ann Zool Fenn 51:227-244 
Fariña RA (1996) Trophic relationships among Lujanian mammals. Evol Theory 11:125-134

Feranec RS (2003) Stable isotopes, hypsodonty, and the paleodiet of Hemiauchenia (Mammalia: Camelidae): a morphological specialization creating ecological generalization. Paleobiology 29:230-242

Fortelius M (1985) Ungulate cheek teeth: developmental, functional and evolutionary interrelations. Acta Zool Fenn 180:1-76

Fortelius M, Solounias N (2000) Functional characterization of ungulate molars using the abrasionattrition wear gradient: a new method for reconstructing paleodiets. Am Mus Novit 3301:1-35

Fortelius M, Eronen JT, Jernvall J, Liu L, Pushkina D et al (2002) Fossil mammals resolve regional patterns of Eurasian climate change during 20 million years. Evol Ecol Res 4:1005-1016

Fortelius M, Eronen J, Liu L, Pushkina D, Tesakov A, Vislobokova I, Zhang Z (2006) Late Miocene and Pliocene large land mammals and climatic changes in Eurasia. Palaeogeogr Palaeoclimatol Palaeoecol 238:219-227

Fortelius M, Zliobaité I, Kaya F, Bibi F, Bobe R, Leakey L, Leakey M, Patterson D, Rannikko J, Werdelin L (2016) An ecometric analysis of the fossil mammal record of the Turkana Basin. Philos Trans R Soc B 371:1-13

Foss SE (2007) Family Entelodontidae. In: Prothero DR, Foss SE (eds) The evolution of artiodactyls. Johns Hopkins University Press, Baltimore, MD, pp 120-129

Franz-Odendaal TA, Lee-Thorp JA, Chinsamy A (2002) New evidence for the lack of C4 grassland expansions during the early Pliocene at Langebaanweg, South Africa. Paleobiology 28:378-388

Fraser D, Zybutz T, Lightner E, Theodor J (2014) Ruminant mandibular tooth mesowear: a new scheme for increasing paleoecological sample sizes. J Zool 294:41-48

Froehlich DJ (2002) Quo vadis eohippus? The systematics and taxonomy of the early Eocene equids (Perissodactyla). Zool J Linnean Soc 134:141-256

Geist V (1998) Deer of the world - their evolution, behaviour, and ecology. Stackpole Books, Mechanicsburg, Pennsylvania

Godthelp H, Archer M, Cifelli R, Hand SJ, Gilkeson CF (1992) Earliest known Australian tertiary mammal fauna. Nature 356:514-516

Gordon IJ (2003) Browsing and grazing ruminants: are they different beasts? For Ecol Manag 181:13-21

Gordon IJ, Prins HHT (2008) The ecology of browsing and grazing, Ecological Studies 195. Springer, Berlin

Green JL, Resar NA (2012) The link between dental microwear and feeding ecology in tree sloths and armadillos (Mammalia: Xenarthra). Biol J Linn Soc 107:277-294

Gregory-Wodzicki KM (2000) Uplift history of the Central and Northern Andes: a review. Geol Soc Am Bull 112:1091-1105

Grossman A, Liutkus-Pierce C, Kyongo B, M'Kirera F (2014) New fauna from Loperot contributes to the understanding of early Miocene catarrhine communities. Int J Primatol 35:1253-1274

Gunnell GF, Murphey PC, Stucky RK, Townsend KEB, Robinson B, Zonneveld J-P, Bartels WS (2009) Biostratigraphy and biochronology of the latest Wasatchian, Bridgerian, and Uintan North American land mammal "ages". Mus North Ariz Bull 65:279-330

Guthrie DR (2001) Origin and causes of the mammoth steppe: a story of cloud cover, woolly mammal tooth pits, buckles, and inside-out Beringia. Quat Sci Rev 20:549-574

Harris JM, Cerling TE, Leakey MG, Passey BH (2008) Stable isotope ecology of fossil hippopotamids from the Lake Turkana Basin of East Africa. J Zool 275:323-331

Hays JD, Imbrie J, Shackleton NJ (1976) Variations in the earth's orbit: pacemaker of the Ice Ages. Science 194:1121-1132

Head MJ (1998) Pollen and dinoflagellates from the Red Crag at Walton-on-the-Naze, Essex: evidence for a mild climatic phase during the early late Pliocene of eastern England. Geol Mag 135:803-817

Herbert TD, Lawrence KT, Tzanova A, Cleaveland-Patterson L, Caballero-Gill R, Kelly CS (2016) Late Miocene global cooling and the rise of modern ecosystems. Nat Geosci 9:843-847 
Hernesniemi E, Blomstedt K, Fortelius M (2011) Multi-view stereo three-dimensional reconstruction of lower molars of recent and Pleistocene rhinoceroses for mesowear analysis. Palaeontol Electron 14:1-15

Hofmann RR, Stewart DRM (1972) Grazer or browser: a classification based on the stomachstructure and feeding habits of East African ruminants. Mammalia 36:226-240

Hooker JJ (2007) Bipedal browsing adaptations of the unusual Late Eocene-earliest Oligocene tylopod Anoplotherium (Artiodactyla, Mammalia). Zool J Linnean Soc 151:609-659

Hooker JJ, Collinson ME (2012) Mammalian faunal turnover across the Palaeocene-Eocene boundary in NW Europe: the roles of displacement, community evolution and environment. Austrian J Earth Sci 105:17-28

Ilius AW, Gordon IJ (1992) Modelling the nutritional ecology of ungulate herbivores: evolution of body size and competitive interactions. Oecologia 89:428-434

Jacobs BF, Kingston JD, Jacobs LL (1999) The origin of grass-dominated ecosystems. Ann Mo Bot Gard 86:590-643

Jacobs BF, Pan AD, Scotese CR (2010) A review of the Cenozoic vegetation history of Africa. In: Werdelin L, Sanders WJ (eds) Cenozoic mammals of Africa. University of California Press, Berkeley, CA, pp 57-72

Janis CM (1976) The evolutionary strategy of the Equidae and the origins of rumen and cecal digestion. Evolution 30:757-774

Janis CM (1982) Evolution of horns in ungulates: ecology and paleoecology. Biol Rev 57:261-318

Janis CM (1993) Tertiary mammal evolution in the context of changing climates, vegetation, and tectonic events. Annu Rev Ecol Syst 24:467-500

Janis CM (1995) Correlation between craniodental morphology and feeding behavior in ungulates: reciprocal illumination between living and fossil taxa. In: Thomason JJ (ed) Functional morphology in vertebrate paleontology. Cambridge University Press, Cambridge, pp 76-98

Janis CM (2007) The horse series. In: Regal B (ed) Icons of evolution. Greenwood Press, West-port, CT, pp 257-280

Janis CM (2008) An evolutionary history of browsing and grazing ungulates. In: Gordon IJ, Prins HHT (eds) The ecology of browsing and grazing, Ecological Studies 195. Springer, Berlin, pp $21-45$

Janis CM, Fortelius M (1988) On the means whereby mammals achieve increased functional durability of their dentitions, with special reference to limiting factors. Biol Rev 63:197-230

Janis CM, Scott KM, Jacobs LL (1998) Evolution of tertiary mammals of North America: volume 1, terrestrial carnivores, ungulates and ungulatelike mammals. Cambridge University Press, Cambridge

Janis CM, Damuth J, Theodor JM (2002) The origins and evolution of the North American grassland biome: the story from the hoofed mammals. Palaeogeogr Palaeoclimatol Palaeoecol 177:183-198

Janis CM, Damuth J, Theodor JM (2004) The species richness of Miocene browsers, and implications for habitat type and primary productivity in the North American grassland biome. Palaeogeogr Palaeoclimatol Palaeoecol 207:371-398

Janis CM, Damuth J, Travouillon KJ, Figueirido B, Hand SJ, Archer M (2016) Palaeoecology of Oligo-Miocene macropodoids determined from craniodental and calcaneal data. Mem Mus Vic 74:209-232

Joomun SC, Hooker JJ, Collinson ME (2008) Dental wear variation and implications for diet: an example from Eocene perissodactyls (Mammalia). Palaeogeogr Palaeoclimatol Palaeoecol 263:92-106

Kahlke R-D (1999) The history of the origin, evolution and dispersal of the late pleistocene Mammuthus-Coelodonta faunal complex in Eurasia (Large Mammals). Rotterdam, the Netherlands

Kahlke R-D, Kaiser TM (2011) Generalism as a subsistence strategy: advantages and limitations of the highly flexible feeding traits of Pleistocene Stephanorhinus hundsheimensis (Rhinocerotidae, Mammalia). Quat Sci Rev 30:2250-2261 
Kaiser TM (2004) The dietary regimes of two contemporaneous populations of Hippotherium primigenium (Perissodactyla, Equidae) from the Vallesian (Upper Miocene) of Southern Germany. Palaeogeogr Palaeoclimatol Palaeoecol 198:381-402

Kaiser TM (2009) Anchitherium aurelianense (Equidae, Mammalia): a brachydont "dirty browser" in the community of herbivorous large mammals from Sandelzhausen (Miocene, Germany). Paläontol Z 83:131-140

Kaiser TM (2011) Feeding ecology and niche partitioning of Laetoli ungulate faunas. In: Harrison T (ed) Paleontology and geology of Laetoli: human evolution in context: volume 1: geology, geochronology, paleoecology and paleoenvironment. Springer, Dordrecht, pp 329-354

Kaiser TM, Müller DWH, Fortelius M, Schulz E, Codron D, Clauss M (2013) Hypsodonty and tooth facet development in relation to diet and habitat in herbivorous ungulates: implications for understanding tooth wear. Mammal Rev 43:34-46

Konidaris GE, Koufos GD, Kostopoulos DS, Merceron G (2016) Taxonomy, biostratigraphy and palaeoecology of Choerolophodon (Proboscidea, Mammalia) in the Miocene of SE Europe SW Asia: implications for phylogeny and biogeography. J Syst Palaeontol 14:1-27

Kovar-Eder J, Jechorek H, Kvaček Z, Parashiv V (2008) The integrated plant record: an essential tool for reconstructing Neogene zonal vegetation in Europe. PALAIOS 23:97-111

Kurtén B (1968) Pleistocene mammals of Europe. Aldine, Chicago

Kurtén B (1972) The ice age. Hart-Davis, London

Kurtén B, Anderson E (1980) Pleistocene mammals of North America. Columbia University Press, New York

Lander B (1998) Oreodontoidea. In: Janis CM, Scott KM, Jacobs LL (eds) Evolution of tertiary mammals of North America: volume 1, terrestrial carnivores, ungulates and ungulatelike mammals. Cambridge University Press, Cambridge, pp 402-425

Lee-Thorp J, van der Merwe NJ (1987) Carbon isotope analysis of fossil bone apatite. S Afr J Sci $83: 712-715$

Lihoreau F, Ducrocq S (2007) Family Anthracotheriidae. In: Prothero DR, Foss SE (eds) The evolution of artiodactyls. Johns Hopkins University Press, Baltimore, MD, pp 89-105

Lisiecki LE, Raymo ME (2007) Plio-Pleistocene climate evolution: trends and transitions in glacial cycle dynamics. Quat Sci Rev 26:56-69

Lister AM (2013) The role of behaviour in adaptive morphological evolution of African proboscideans. Nature 500:331-334

Lister AM, Sher AV, van Essen H, Wei G (2005) The pattern and process of mammoth evolution in Eurasia. Quat Int 126-128:49-64

Liu L-P (2001) Eocene suoids (Artiodactyla, Mammalia) from Bose and Yongle basins, China and the classification and evolution of the Paleogene suoids. Vertebrata Pal Asiatica 39:115-128

Liu L-P, Eronen JT, Fortelius M (2009) Significant mid-latitude aridity in the middle Miocene of East Asia. Palaeogeogr Palaeoclimatol Palaeoecol 279:201-206

Loffredo LF, DeSantis LRG (2014) Cautionary lessons from assessing dental mesowear observer variability and integrating paleoecological proxies of an extreme generalist Cormohipparion emsliei. Palaeogeogr Palaeoclimatol Palaeoecol 395:42-52

Loose HK (1975) Pleistocene Rhinocerotidae of W. Europe with reference to the recent two-horned species of Africa and S.E. Asia. Scr Geol 33:1-59

Louys J, Aplin K, Beck RMD, Archer M (2009) Cranial anatomy of Oligo-Miocene koalas (Diprotodontia: Phascolarctidae): stages in the evolution of an extreme leaf-eating specialization. J Vertebr Paleontol 29:981-992

Lucas PW, Omar R (2012) New perspectives of tooth wear. Int J Dent 2012. https://doi.org/10. $1155 / 2012 / 287573$

Lucas SG, Schoch RM (1998) Tillodontia. In: Janis CM, Scott KM, Jacobs LL (eds) Evolution of tertiary mammals of North America: volume 1, terrestrial carnivores, ungulates and ungulatelike mammals. Cambridge University Press, Cambridge, pp 268-273

Lucas SG, Schoch RM, Williamson TE (1998) Taeniodonta. In: Janis CM, Scott KM, Jacobs LL (eds) Evolution of tertiary mammals of North America: volume 1, terrestrial carnivores, ungulates and ungulatelike mammals. Cambridge University Press, Cambridge, pp 260-267 
Lucas PW, van Casteren A, Al-Fadhalan K, Almusallam AS, Henry AG, Michael S, Watzke J, Reed DA, Diekwisch TGH, Strait DS, Atkins AG (2014) The role of dust, grit and phytoliths in tooth wear. Ann Zool Fenn 51:143-152

MacFadden BJ (2000) Cenozoic mammalian herbivores from the Americas: reconstructing ancient diets and terrestrial communities. Annu Rev Ecol Syst 31:33-59

MacFadden BJ, Wang Y, Cerling TE, Anaya F (1994) South American fossil mammals and carbon isotopes: a 25 million-year sequence from the Bolivian Andes. Palaeogeogr Palaeoclimatol Palaeoecol 107:257-268

MacFadden BJ, Cerling TE, Prado J (1996) Cenozoic terrestrial ecosystem evolution in Argentina: evidence from carbon isotopes of fossil mammal teeth. PALAIOS 11:319-327

Madden RH (2015) Hypsodonty in mammals. Cambridge University Press, Cambridge

Maglio VJ (1973) Origin and evolution of the Elephantidae. Trans Am Philos Soc 63:1-149

Mead AJ, Wall WP (1998) Dietary implications of jaw mechanics in the rhinocerotoids Hyracodon and Subhyracodon from Badlands National Park, South Dakota. In: McClelland L (ed) Santucci VL. National Park Service Paleontological Research, National Park Service, pp 18-23

Métais G, Chaimanee Y, Jaeger J-J, Ducrocq S (2001) New remains of primitive ruminants from Thailand: evidence of the early evolution of the Ruminantia in Asia. Zool Scr 30:231-248

Métais G, Antoine P-O, Marivaux L, Welcomme J-L, Ducrocq S (2003) New artiodactyl ruminant mammal from the late Oligocene of Pakistan. Acta Palaeontol Pol 48:375-382

Métais G, Qi T, Guo J, Beard KC (2005) A new bunoselenodont artiodactyl from the Middle Eocene of China and the early record of selenodont artiodactyls in Asia. J Vertebr Paleontol 25:994-997

Métais G, Welcomme J-L, Ducrocq S (2009) New lophiomerycid ruminants from the Oligocene of the Bugti Hills (Balochistan, Pakistan). J Vertebr Paleontol 29:231-241

Mihlbachler MC (2008) Species taxonomy, phylogeny, and biogeography of the Brontotheriidae (Mammalia: Perissodactyla). Bull Am Mus Nat Hist 311:1-475

Mihlbachler MC, Solounias M (2006) Coevolution of tooth crown height and diet in oreodonts (Merycoidodontidae, Artiodactyla) examined with phylogenetically independent contrasts. J Mamm Evol 13:11-36

Mihlbachler MC, Rivals F, Solounias N, Semprebon GM (2011) Dietary change and evolution of horses in North America. Science 331:1178-1181

Montanari S, Louys J, Price GJ (2013) Pliocene paleoenvironments of southeastern Queensland, Australia, inferred from stable isotopes of marsupial tooth enamel. PLoS One 8:e66221

Morgan GS, Lucas SG (2003) Mammalian biochronology of Blancan and Irvingtonian (Pliocene and early Pleistocene) faunas from New Mexico. Bull Am Mus Nat Hist 279:269-320

Noret J, Tabor NI, Jacobs BF, Sanders WJ, Kappelman J (2012) Stable isotope data from the Chilga Basin, Ethiopia, and their implications for resource partitioning among late Paleogene African endemic mammals. J Vertebr Paleontol 32(Suppl 2):150

Novello A, Blondel C, Brunet M (2010) Feeding behavior and ecology of the late Oligocene Moschidae (Mammalia, Ruminantia) from La Milloque (France): evidence from dental microwear analysis. C R Palevol 9:471-478

Orliac MJ, Antoine P-O, Roohi G, Welcomme J-L (2010) Suoidea (Mammalia, Cetartiodactyla) from the early Oligocene of the Bugti Hills, Balochistan, Pakistan. J Vertebr Paleontol 30:1300-1305

Ortiz-Jaureguizar E, Cladera GA (2006) Paleoenvironmental evolution of southern South America during the Cenozoic. J Arid Environ 66:498-532

Passey BH, Eronen JT, Fortelius M (2007) Paleodiets and paleoenvironments of late Miocene gazelles from North China: evidence from stable carbon isotopes. Vertebrata Pal Asiatica 45:118-127

Patnaik R (2015) Diet and habitat changes among Siwalik herbivorous mammals in response to Neogene and quaternary climate changes: an appraisal in the light of new data. Quat Int 371:232-243 
Prasad V, Strömberg CAE, Alimohammadian H, Sahni A (2005) Dinosaur coprolites and the early evolution of grasses and grazers. Science 310:1177-1180

Prideaux GJ, Ayliffe LK, DeSantis LGR, Schubert BW, Murray PF, Gagan MK, Cerling TE (2009) Extinction implications of a chenopod browse diet for a giant Pleistocene kangaroo. PNAS 106:11646-11650

Prothero DR (1998) Protoceratidae. In: Janis CM, Scott KM, Jacobs LL (eds) Evolution of tertiary mammals of North America: volume 1, terrestrial carnivores, ungulates and ungulatelike mammals. Cambridge University Press, Cambridge, pp 431-438

Prothero DR (2013) Rhinoceros giants: the paleobiology of indricotheres. Indiana University Press, Bloomington, IN

Prothero DR, Manning E, Hanson CB (1986) The phylogeny of the Rhinocerotoidea (Mammalia, Perissodactyla). Zool J Linnean Soc 87:341-366

Prothero DR, Guérin C, Manning E (1989) The history of the Rhinocerotoidea. In: Prothero DR, Schoch RM (eds) The evolution of Perissodactyls. Oxford University Press, New York, pp 321-340

Pushkina D (2007) The Pleistocene easternmost distribution in Eurasia of the species associated with the Eemian Palaeoloxodon antiquus assemblage. Mammal Rev 37:224-245

Raia P, Carotenuto F, Passaro F, Piras P, Fulgione D, Werdelin L, Saarinen J, Fortelius M (2013) Rapid action in the Palaeogene, the relationship between phenotypic and taxonomic diversification in Cenozoic mammals. Proc R Soc B Biol Sci 280:2012-2244

Rasmussen DT, Gutiérrez M (2010) Hyracoidea. In: Werdelin L, Sanders WJ (eds) Cenozoic mammals of Africa. University of California Press, Berkeley, CA, pp 124-146

Reguero MA, Candela AM, Cassini GH (2010) Hypsodonty and body size in rodent-like notoungulates. In: Madden RH, Carlini AA, Vucetich MG, Kay RF (eds) The paleontology of gran Barranca: evolution and environmental change through the middle Cenozoic of Patagonia. Cambridge University Press, Cambridge, pp 362-371

Retallack GJ (1992) Middle Miocene fossil plants from fort Ternan (Kenya) and evolution of African grasslands. Paleobiology 18:383-400

Retallack GJ, Wynn JG, Benefit BR, Mccrossin ML (2002) Paleosols and paleoenvironments of the middle Miocene, Maboko formation, Kenya. J Hum Evol 42:659-703

Rivals F, Deniaux B (2003) Dental microwear analysis for investigating the diet of an argali population (Ovis ammon antiqua) of mid-Pleistocene age, Caune de l'Arago cave, eastern Pyrenees, France. Palaeogeogr Palaeoclimatol Palaeoecol 193:443-455

Rivals F, Deniaux B (2005) Investigation of human hunting seasonality through dental microwear analysis of two Caprinae in late Pleistocene localities in Southern France. J Archaeol Sci 32:1603-1612

Rivals F, Lister AM (2016) Dietary flexibility and niche partitioning of large herbivores through the Pleistocene of Britain. Quat Sci Rev 146:116-133

Rivals F, Solounias N, Mihlbachler MC (2007) Evidence for geographic variation in the diets of late Pleistocene and early Holocene Bison in North America, and differences from the diets of recent Bison. Quat Res:68338-68346

Rivals F, Mihlbachler MC, Solounias N, Mol D, Semprebon GM, de Vos J, Kalthoff DC (2010) Palaeoecology of the Mammoth Steppe fauna from the late Pleistocene of the North Sea and Alaska: separating species preferences from geographic influence in paleoecological dental wear analysis. Palaeogeogr Palaeoclimatol Palaeoecol 286:42-54

Rivals F, Semprebon G, Lister A (2012) An examination of dietary diversity patterns in Pleistocene proboscideans (Mammuthus, Palaeoloxodon, and Mammut) from Europe and North America as revealed by dental microwear. Quat Int 255:188-195

Rivals F, Mol D, Lacombat F, Lister AM, Semprebon GM (2015) Resource partitioning and niche separation between mammoths (Mammuthus rumanus and Mammuthus meridionalis) and gomphotheres (Anancus arvernensis) in the early Pleistocene of Europe. Quat Int 379:164-170

Rögl F (1998) Palaeogeographic considerations for Mediterranean and Paratethys seaways (Oligocene to Miocene). Annalen des Naturhistorischen Museums in Wien 99A:279-310 
Rose KD (1981) Composition and species diversity in Paleocene and Eocene mammal assemblages: an empirical study. J Vertebr Paleontol 1:367-388

Rose KD (2006) The beginning of the age of mammals. Johns Hopkins University Press, Baltimore, MD

Rowan J, Faith JT, Gebru Y, Feagle JG (2015) Taxonomy and paleoecology of fossil Bovidae (Mammalia, Artiodactyla) from the Kibish formation, southern Ethiopia: implications for dietary change, biogeography, and the structure of the living bovid faunas of East Africa. Palaeogeogr Palaeoclimatol Palaeoecol 420:210-222

Saarinen J, Karme A (2017) Tooth wear and diets of extant and fossil xenarthrans (Mammalia, Xenarthra) - applying a new mesowear approach. Palaeogeogr Palaeoclimatol Palaeoecol 476:42-54

Saarinen J, Lister AM (2016) Dental mesowear reflects local vegetation and niche separation in Pleistocene proboscideans from Britain. J Quat Sci 31:799-808

Saarinen J, Boyer AG, Brown JH, Costa DB, Ernest SKM, Evans AR, Fortelius M, Gittleman JL, Hamilton MJ, Harding LE, Lintulaakso K, Lyons SK, Okie JG, Sibly RM, Stephens PR, Theodor J, Uhen MD, Smith FA (2014) Patterns of body size evolution in Cenozoic land mammals: intrinsic biological processes and extrinsic forcing. Proc R Soc B Biol Sci 281:20132049. https://doi.org/10.1098/rspb.2013.2049

Saarinen J, Karme A, Cerling T, Uno K, Säilä L, Kasiki S, Ngene S, Obari T, Mbua E, Manthi FK, Fortelius M (2015) A new tooth wear -based dietary analysis method for Proboscidea (Mammalia). J Vertebr Paleontol 35. https://doi.org/10.1080/02724634.2014.918546

Saarinen J, Eronen J, Fortelius M, Seppä H, Lister AM (2016) Patterns of diet and body mass of large ungulates from the Pleistocene of Western Europe, and their relation to vegetation. Palaeontol Electron 19.3.32A:1-58. palaeo-electronica.org/content/2016/1567-pleistocenemammal-ecometrics

Samuels JX, Bredehoeft KE, Wallace SC (2018) A new species of Gulo from the Early Pliocene Gray Fossil Site (Eastern United States); rethinking the evolution of wolverines. PeerJ 6:e4648. https://doi.org/10.7717/peerj.4648

Sánchez B, Prado JL, Alberdi MT (2004) Feeding ecology, dispersal, and extinction of South American Pleistocene gomphotheres (Gomphotheriidae, Proboscidea). Paleobiology 30:146-161

Sanders WJ, Kappelman J, Rasmussen TD (2004) New large bodied mammals from the late Oligocene site of Chilga, Ethiopia. Acta Palaeontol Pol 49:365-392

Sanders WJ, Gheerbrant E, Harris JM, Saegusa H, Delmer C (2010) Proboscidea. In: Werdelin L, Sanders WJ (eds) Cenozoic mammals of Africa. University of California Press, Berkeley, CA, pp 124-146

Schmidt CW (2008) Dental microwear analysis of extinct flat-headed peccary (Platygonus compressus) from Southern Indiana. Proc Indiana Acad Sci 117:95-106

Scott RS, Ungar PS, Bergstrom TS, Brown CA, Grine FE, Teaford MF, Walker A (2005) Dental microwear texture analysis shows within-species diet variability in fossil hominins. Nature 436:693-695

Semprebon GM, Rivals F (2007) Was grass more prevalent in the pronghorn past? An assessment of the dietary adaptations of Miocene to recent Antilocapridae (Mammalia: Artiodactyla). Palaeogeogr Palaeoclimatol Palaeoecol 253:332-347

Semprebon GM, Rivals F (2010) Trends in the paleodietary habits of fossil camels from the tertiary and quaternary of North America. Palaeogeogr Palaeoclimatol Palaeoecol 295:131-145

Semprebon GM, Janis CM, Solounias N (2004) The diets of the Dromomerycidae (Mammalia: Artiodactyla) and their response to Miocene vegetational change. J Vertebr Paleontol 24:427-444

Semprebon GM, Sise PJ, Coombs MC (2011) Potential bark and fruit browsing as revealed by stereomicrowear analysis of the peculiar clawed herbivores known as chalicotheres (Perissodactyla, Chalicotherioidea). J Mamm Evol 18:33-55 
Semprebon GM, Rivals F, Solounias N, Hulbert RC Jr (2016a) Paleodietary reconstruction of fossil horses from the Eocene through Pleistocene of North America. Palaeogeogr Palaeoclimatol Palaeoecol 442:110-127

Semprebon GM, Tao D, Hasjanova J, Solounias N (2016b) An examination of the dietary habits of Platybelodon grangeri from the Linxia Basin of China: evidence from dental microwear of molar teeth and tusks. Palaeogeogr Palaeoclimatol Palaeoecol 457:109-116

Shockey BJ, Anaya F (2011) Grazing in a new late Oligocene mylodontid sloth and a mylodontid radiation as a component of the Eocene-Oligocene faunal turnover and the early spread of grasslands/savannas in South America. J Mamm Evol 18:101-115

Smith FA, Boyer AG, Brown JH, Costa DP, Dayan T, Ernest SKM, Evans AR, Fortelius M, Gittleman J, Hamilton MJ, Harding LE, Lintulaakso K, Lyons SK, McCain C, Okie JK, Saarinen J, Sibly RM, Stephens PR, Theodor J, Uhen MD (2010) The evolution of maximum body size of terrestrial mammals. Science 330:1216-1219

Solounias N, Rivals F, Semprebon GM (2010) Dietary interpretation and paleoecology of herbivores from Pikermi and Samos (Late Miocene of Greece). Paleobiology 36:113-136

Solounias N, Semprebon GM, Mihlbachler MC, Rivals F (2013) Paleodietary comparisons of ungulates between the late Miocene of China, and Pikermi and Samos in Greece. In: Wang X, Flynn LJ, Fortelius M (eds) Fossil mammals of Asia: Neogene biostratigraphy and chronology, Columbia University Press, New York, p 676-692

Solounias N, Tariq M, Hou S, Danowitz M, Harrison M (2014) A new method of tooth mesowear and a test of it on domestic goats. Ann Zool Fenn 51:111-118

Stevens MS, Stevens JB (2007) Family Merycoidodontidae. In: Prothero DR, Foss SE (eds) The evolution of artiodactyls. Johns Hopkins University Press, Baltimore, pp 157-168

Strani F, DeMiguel D, Sardella R, Bellucci L (2015) Paleoenvironments and climatic changes in the Italian Peninsula during the early Pleistocene: evidence from dental wear patterns of the ungulate community of Coste San Giacomo. Quat Sci Rev 121:28-35

Strömberg CAE (2011) Evolution of grasses and grassland ecosystems. Annu Rev Earth Planet Sci 39:517-544

Strömberg CAE, McInerney FA (2011) The Neogene transition from C3 to C4 grasslands in North America: assemblage analysis of fossil phytoliths. Paleobiology 37:50-71

Strömberg CAE, Dunn RE, Madden RH, Kohn MJ, Carlini AA (2013) Decoupling the spread of grasslands from the evolution of grazer-type herbivores in South America. Nat Commun 4 (1478): $1-8$

Stuart AJ (1976) The history of the mammal fauna during the Ipswichian/last interglacial in England. Philos Trans R Soc B 276:221-250

Sturm M (1978) Maw contents of an Eocene horse (Propalaeotherium) out of the oil shale of Messel near Darmstadt. In: Kvacek Z, Schaarschmidt F (eds) Advances in angiosperm Palaeobotany, vol 30. Courier Forschungsinstitut, Senckenberg, pp 2-120

Sun J, Windley BF (2015) Onset of aridification by 34 Ma across the Eocene-Oligocene transition in Central Asia. Geology 43:1015-1018

Tang Z-H, Ding Z-L (2013) A palynological insight into the Miocene aridification in the Eurasian interior. Palaeoworld 22:77-85

Townsend KEB, Croft DA (2008) Diets of notoungulates from the Santa Cruz formation, Argentina: new evidence from enamel microwear. J Vertebr Paleontol 28:217-230

Travouillon KJ, Legendre S, Archer M, Hand SJ (2009) Palaeoecological analyses of Riversleigh's Oligo-Miocene sites: implications for Oligo-Miocene climate change in Australia. Palaeogeogr Palaeoclimatol Palaeoecol 276:24-37

Ulbricht A, Maul LC, Schulz E (2015) Can mesowear analysis be applied to small mammals? A pilot-study on leporines and murines. Mamm Biol 80:14-20

Ungar PS (2010) Mammal teeth: origin, evolution and diversity. Johns Hopkins University Press, Baltimore, MD

Ungar PS, Brown CA, Bergstrom TS, Walker A (2003) A quantification of dental microwear by tandem scanning confocal microscopy and scale-sensitive fractal analyses. Scanning 25:189-193 
Uno KT, Cerling TE, Harris JM, Kunimatsu Y, Leakey MG, Nakatsukasa M, Nakaya H (2011) Late Miocene to Pliocene carbon isotope record of differential diet change among East African herbivores. PNAS 108:6509-6514

Urban MA, Nelson DM, Jiménez-Moreno G, Châteauneuf J-J, Pearson A, Hu FS (2010) Isotopic evidence of $\mathrm{C} 4$ grasses in southwestern Europe during the Early Oligocene-Middle Miocene. Geology 38:1091-1094

Valli AF, Palombo MR (2008) Feeding behaviour of middle-size deer from the Upper Pliocene site of Saint-Vallier (France) inferred by morphological and micro/mesowear analysis. Palaeogeogr Palaeoclimatol Palaeoecol 257:106-122

Van Asperen E, Kahlke R-D (2015) Dietary variation and overlap in Central and Northwest European Stephanorhinus kirchbergensis and S. hemitoechus (Rhinocerotidae, Mammalia) influenced by habitat diversity: "You'll have to take pot luck!" (proverb). Quat Sci Rev 107:47-61

Van Devender TR, McClaran MP (1995) Desert grassland history. In: McClaran MP, Van Devender TR (eds) The desert grassland. The University of Arizona Press, Tucson, Arizona, pp 68-99

Vicentini A, Barber JC, Aliscioni SS, Giussani LM, Kellogg EA (2008) The age of the grasses and clusters of origins of C4 photosynthesis. Glob Chang Biol 14:2963-2977

Vizcaíno SF (2009) The teeth of the "toothless": novelties and key innovations in the evolution of xenarthrans (Mammalia, Xenarthra). Palaeobiology 35:343-366

Walker M, Lowe J (2007) Quaternary science 2007: a 50-year retrospective. J Geol Soc 164:1073-1092

Walker A, Hoeck HN, Perez L (1978) Microwear of mammalian teeth as an indicator of diet. Science 201:908-910

Wall WP (1998) Amynodontidae. In: Janis CM, Scott KM, Jacobs LL (eds) Evolution of tertiary mammals of North America: volume 1, terrestrial carnivores, ungulates and ungulatelike mammals. Cambridge University Press, Cambridge, pp 583-588

Wang B (1992) The Chinese Oligocene: a preliminary review of mammalian localities and local faunas. In: Prothero DR, Berggren WA (eds) Eocene-Oligocene climatic and biotic evolution. Princeton University Press, Princeton, pp 529-547

Wang Y, Meng J, Ni X, Li C (2007) Major events in Paleogene mammal radiation in China. Geol J 42:415-430

Wang Y, Xu Y, Khawaja S, Passey BH, Zhang C, Wang X, Li Q, Tseng ZJ, Takeuchi GT, Deng T, Xie G (2013) Diet and environment of a mid-Pliocene fauna from southwestern Himalaya: Paleo-elevation implications. Earth Planet Sci Lett 376:43-53

Wang X, Li Q, Takeuchi GT (2016) Out of Tibet: an early sheep from the Pliocene of Tibet, Protovis himalayensis, genus and species nov. (Bovidae, Caprini), and origin of Ice Age mountain sheep. J Vertebr Paleontol 36:5, e1169190. https://doi.org/10.1080/02724634.2016. 1169190

Werdelin L, Sanders WJ (2010) Cenozoic mammals of Africa. University of California Press, Berkeley, CA

West RG (1980) The pre-glacial Pleistocene of the Suffolk and Norfolk Coasts. Cambridge University Press, Cambridge

Wilde V, Hellmund M (2010) First record of gut contents from a middle Eocene equid from the Geiseltal near Halle (Saale), Sachsen-Anhalt, Central Germany. Palaeobiodivers Palaeoenviron 90:153-162

Williams M, Dunkerley D, De Deckker P, Kershaw P, Chappell J (1998) Quaternary environments. Arnold, London

Williamson TE, Lucas SG (1992) Meniscotherium (Mammalia, "Condylarthra") from the Palaeocene-Eocene of Western North America. BullMexico Mus Nat Hist Sci 1:1-75

Woodburne MO (2010) The great American Biotic Interchange: dispersals, tectonics, climate, sea level and holding pens. J Mamm Evol 17:245-264 
Woodburne MO, Case JA (1996) Dispersal, vicariance, and the Late Cretaceous to early tertiary land mammal biogeography from South America to Australia. J Mamm Evol 3:121-161

Wu Y, Deng T, Ma J, Zhou X, Mao L, Zhang H, Ye J, Wang S-Q (2018) A grazing Gomphotherium in Middle Miocene Central Asia, 10 million years prior to the origin of the Elephantidae. Sci Rep 8:7640. https://doi.org/10.1038/s41598-018-25909-4

Zachos JC, Pagani M, Sloan L, Thomas E, Billups K (2001) Trends, rhythms and aberrations in global climate 65 Ma to present. Science 292:686-693

Zachos JC, Dickens GR, Zeebe RE (2008) An early Cenozoic perspective on greenhouse warming and carbon-cycle dynamics. Nature 451:279-283

Zanazzi A, Kohn MJ (2008) Ecology and physiology of White River mammals based on stable isotope ratios of teeth. Palaeogeogr Palaeoclimatol Palaeoecol 257:22-37

Zaw K, Meffre S, Takai M, Suzuki H, Burret C, Htike T, Thein ZMM, Tsubamoto T, Egi N, Maung M (2014) The oldest anthropoid primates in SE Asia: Evidence from LA-ICP-MS U-Pb zircon age in the Late Middle Eocene Pondaung formation, Myanmar. Gondwana Res 26:122-131

Zhang H, Wang Y, Janis CM, Goodall RH, Purnell MA (2017) An examination of feeding ecology in Pleistocene proboscideans from southern China (Sinomastodon, Stegodon, Elephas), by means of dental microwear texture analysis. Quat Int 445:60-70

Zhegallo V, Kalandadze N, Shapovalov A, Bessudnova Z, Noskova N, Tesakova E (2005) On the fossil rhinoceros Elasmotherium (including the collections of the Russian Academy of Sciences). Cranium 22:17-40

Zimov SA, Chuprynin VI, Oreshko AP, Chapin FS III, Reynolds JF, Chapin MC (1995) Steppetundra transition: a herbivore-driven biome shift at the end of the Pleistocene. Am Nat 146:765-794

Žliobaitė I, Rinne J, Tóth AB, Mechenich M, Liu L, Behrensmeyer AK, Fortelius M (2016) Herbivore teeth predict climatic limits in Kenyan ecosystems. PNAS 45:12751-12756

Žliobaitė I, Tang H, Saarinen J, Fortelius M, Rinne J, Rannikko J (2018) Dental ecometrics of tropical Africa: linking vegetation types and communities of large plant-eating mammals. Evol Ecol Res 19:127-147 